NBER WORKING PAPER SERIES

\title{
ALCOHOL PROHIBITION AND CIRRHOSIS
}

\author{
Angela K. Dills \\ Jeffrey A. Miron \\ Working Paper 9681 \\ http://www.nber.org/papers/w9681

\section{NATIONAL BUREAU OF ECONOMIC RESEARCH} \\ 1050 Massachusetts Avenue \\ Cambridge, MA 02138 \\ May 2003
}

We thank Sam Peltzman and Kevin Lang for useful comments. The views expressed herein are those of the authors and not necessarily those of the National Bureau of Economic Research.

(C)2003 by Angela K. Dills and Jeffrey A. Miron. All rights reserved. Short sections of text not to exceed two paragraphs, may be quoted without explicit permission provided that full credit including Cnotice, is given to the source. 
Alcohol Prohibition and Cirrhosis

Angela K.Dills and Jeffrey A. Miron

NBER Working Paper No. 9681

May 2003

JEL No. I1, J1, K4, N4

\section{ABSTRACT}

This paper uses state-level data on cirrhosis death rates to examine the impact of state prohibitions, pre-1920 federal anti-alcohol policies, and constitutional prohibition on cirrhosis. State prohibitions had a minimal impact on cirrhosis, especially during the pre-1920 period. Pre-1920 federal antialcohol policies may have contributed to the decline in cirrhosis that occurred before 1920, although other factors were likely substantial influences as well. Constitutional prohibition reduced cirrhosis by about 10-20 percent.

\author{
Angela K. Dills \\ Department of Economics \\ Clemson University \\ Clemson, SC 29634-1309 \\ adills@clemson.edu
}

Jeffrey A. Miron

Department of Economics

Boston University

Boston, MA 02215

and NBER

jmiron@bu.edu 


\section{Introduction}

The U.S. experience with national prohibition of alcohol plays a frequent role in discussions of government policy toward alcohol, drugs and other commodities. Central to this debate is whether, or to what degree, Prohibition reduced consumption of alcohol. Data on alcohol consumption are not available for the Prohibition period, however, so numerous authors have used the cirrhosis death rate to infer the behavior of alcohol consumption. Focusing on comparisons of the pre-Prohibition and early Prohibition periods, these authors have suggested that Prohibition caused as much as a $50 \%$ decline in cirrhosis. ${ }^{1}$

Existing analyses of Prohibition and cirrhosis are potentially problematic, however. Most analyses have focused on the univariate behavior of cirrhosis and conducted simple comparisons of the pre-Prohibition and Prohibition periods. This approach ignores other Prohibition-era changes in alcohol-control policies, including state prohibitions, wartime prohibition, and increased alcohol taxation. Likewise, the univariate approach fails to account for the many nonpolicy variables that might affect cirrhosis, including social attitudes, income, war, and demographics.

This paper evaluates the impact of Prohibition on cirrhosis death rates, and it considers the possible implications for understanding the effects of prohibitions generally.

Section 2 re-examines the relation between cirrhosis and alcohol consumption. Both biomedical research and comparisons across countries or time periods suggest alcohol consumption is an important determinant of cirrhosis. Using cirrhosis to infer Prohibition's impact on alcohol consumption, however, assumes that short-term fluctuations in cirrhosis are reasonable proxies 
for short-term fluctuations in alcohol consumption. We document that the time-series variation in alcohol consumption explains much of the time-series variation in cirrhosis, but the relation is far from perfect. More importantly, various aspects of the relation need to be accounted for if the behavior of cirrhosis is to suggest conclusions about alcohol consumption.

Section 3 begins our examination of Prohibition's impact on cirrhosis. We show that cirrhosis was lower during Prohibition than in most years before or after, which makes a prima facie case that Prohibition reduced cirrhosis. Further examination, however, suggests caution in drawing this conclusion. First, there have been substantial fluctuations in cirrhosis outside the Prohibition period, which suggests that factors other than Prohibition should be considered before concluding that Prohibition caused the low level during Prohibition. Second, cirrhosis did not jump dramatically upon repeal of Prohibition, which fails to suggest an important effect of Prohibition. Most importantly, cirrhosis had fallen to its low, Prohibition level by the time Prohibition began, which means Prohibition did not cause the low level of cirrhosis at the beginning of Prohibition.

Section 4 then presents regressions of state-level cirrhosis death rates on measures of state prohibition, constitutional prohibition, and other variables. These regressions suggest that state-level prohibition had only a small impact on cirrhosis; instead, one or more aggregate factors caused a major decline in cirrhosis during the 1917-1919 period. Pre-1920 federal antialcohol policies might have contributed to this decline, but other factors were likely important influences as well. Whatever caused the pre-1920 decline, constitutional Prohibition lowered the cirrhosis death rate by about $10-20 \%$.

\footnotetext{
${ }^{1}$ See, for example, Aaron and Musto (1981), Moore and Gerstein (1981), Edwards et al. (1994), Musto (1996), MacCoun and Reuter (2001), and Yoon et. al (2001).
} 
Section 5 discusses possible implications of the results.

\section{The Relation between Alcohol Consumption and Cirrhosis}

As noted above, most literature on the relation between Alcohol Prohibition and alcohol consumption uses cirrhosis death rates as a proxy for alcohol consumption. ${ }^{2}$ No one doubts that cirrhosis is a reasonable indicator of alcohol consumption in many contexts: extensive biomedical evidence concludes that alcohol consumption causes most cirrhosis (e.g., Berkow (1992, pp. 890-897)). Whether cirrhosis is a useful proxy in all settings, however, depends on specific aspects of the relation between consumption and cirrhosis. In this section we examine data on alcohol consumption and cirrhosis, with particular attention to the aspects of this relation relevant to the study of Prohibition.

Figure 1 presents cross-country evidence on the relation between cirrhosis and alcohol consumption. The figure plots the average cirrhosis death rate against average alcohol consumption per capita over roughly the period 1954-1995 for sixteen countries. ${ }^{3}$ The cirrhosis death rates are measured as the number of cirrhosis deaths per 100,000 persons; thus, they are

\footnotetext{
${ }^{2}$ Other proxy series include the drunkenness arrest rate, deaths from alcoholism, admittances to mental hospitals for alcoholic psychosis, industrial efficiency, the industrial accident rate, and the automobile accident rate; see, in particular, Warburton (1932). Additional work on the determinants of alcohol consumption uses cirrhosis as a proxy outside the Prohibition period, since state-level data on alcohol consumption do not exist. See, for example, Cook (1981) or Cook and Tauchen (1982).

${ }^{3}$ The countries are Australia, Austria, Belgium, Canada, the Czech Republic, Denmark, Finland, France, Hungary, Ireland, Italy, the Netherlands, Norway, Sweden, the United Kingdom, and the United States.
} 
crude rather than age-adjusted death rates. ${ }^{4}$ The alcohol consumption data are measured in pure liters of alcohol per capita, computed as the alcohol-adjusted sum of beer, wine, and spirits. ${ }^{5}$

The data in the figure display a strong, positive correlation between average alcohol consumption and average cirrhosis death rates; the estimated correlation is 0.75 , which is significant at the 0.001 level. The correlation is far from perfect, however. For example, Austria, Italy and Hungary appear to be outliers. More importantly, the fact that the levels of the two variables are correlated on average is not sufficient to justify using cirrhosis for the timeseries analysis considered below.

Figures $2 \mathrm{a}$ and $2 \mathrm{~b}$ present the annual time-series data on cirrhosis and consumption that underlie the averages for the sixteen countries. The data are consistent with a positive effect of alcohol consumption on cirrhosis, but the evidence is far from overwhelming. In several countries the correlation is consistently positive, and this occurs with respect to both increases and decreases in cirrhosis (e.g., Australia, Belgium, Canada, Italy, the Netherlands, Norway, Sweden, and the U.S.). In several other countries the correlation is positive, but this mainly reflects a common upward trend over the sample period (e.g., Austria, Czech Republic, Denmark, Hungary, U.K., and Ireland). And in many countries, there is substantial variation in cirrhosis that is not present in alcohol consumption. In some cases this variation has the

\footnotetext{
${ }^{4}$ Age-adjusted death rates are not available for most countries. We provide a crude correction for changes in the age composition of the population in the regression analysis below. Cirrhosis death rates are from the World Health Organization's World Health Statistics Annual, various years.

${ }^{5}$ The consumption data are from Brewers Association of Canada (1997), except that those for the U.S. are from Miron (1996). Per capita consumption of absolute alcohol is calculated using the average percentage of alcohol in beer, wine, and spirits in a given country in a given year. Generally these percentages are $4.5-5 \%$ for beer, $10-16 \%$ for wine, and $40-45 \%$ for spirits.
} 
appearance of random measurement error, but in other cases it suggests that additional factors are at work (e.g., Netherlands, Sweden, Ireland, France).

Table 1 confirms these impressions by reporting regressions of the cirrhosis death rate on alcohol consumption per capita. ${ }^{6}$ Consumption always enters positively and usually statistically significantly. Consistent with the figures, however, the coefficients vary substantially in magnitude and significance. Although contemporaneous consumption is an important determinant of cirrhosis, other factors matter as well. ${ }^{7}$

Table 2 considers a first such factor by adding the lag of alcohol consumption to the regressions. The last column shows the sum of the coefficients on current and lagged consumption. The lagged value of consumption sometimes enters positively and significantly, but the results are not particularly consistent. In many cases the second lag enters negatively rather than positively. In a number of other cases the second lag enters positively, but the contemporaneous value becomes negative. And when the lag enters positively, the coefficient on the second lag is sometimes larger than the coefficient on contemporaneous consumption. The second to last column does indicate that the sum of the lag coefficients is always positive, and the range of estimated "impacts" is fairly tight. Regressions using longer lags yield similar results; the sum of the lag coefficients is always positive, but there is considerable noise in the individual coefficients on current and lagged consumption. These regressions thus confirm that

\footnotetext{
${ }^{6}$ We also estimate Tables 1-5 including a time trend, with similar results.

7 The Durbin-Watson statistics from the OLS regressions indicate the presence of positive autocorrelation in most cases. Thus, the estimates in these tables report Newey-West (1987) standard errors.
} 
accounting for lags in the relation between consumption and cirrhosis is important; they do not provide a parsimonious method of accounting for those lags.

Table 3 therefore presents regressions of cirrhosis on lagged cirrhosis and contemporaneous alcohol consumption. This is the correct specification if cirrhosis is a geometric distributed lag of current and past consumption. As in Table 2, the results are consistent overall. Here, however, the U.S. is a glaring exception when estimated over the post-WWII sample; the coefficient on alcohol consumption is negative. Since the U.S. data are the most relevant for our purposes, this result is troubling. When we restrict the sample to the periods "near" Prohibition, however, the estimates are better behaved. And we show below that conditioning on the age and sex structure of the population also eliminates this anomaly.

A potentially important mediating factor between alcohol consumption and the cirrhosis death rate is the age structure of the population. Cirrhosis deaths occur almost exclusively among persons aged 35 and over, particularly those aged $55-75 .{ }^{8}$ To eliminate the effects of changes in the age-composition of the population, time-series analyses often use age-adjusted death rates (Anderson and Rosenberg 1998). We cannot utilize that approach here because agespecific cirrhosis death rates by state, which are crucial for our analysis, are not available before 1920. We show below that an alternative approach yields reasonable answers.

Table 4 repeats the regressions in Table 3 but adding the percentage of the population that is male and the fraction of the population in each of 11 age categories. ${ }^{9}$ For ease of comparison, the

\footnotetext{
${ }^{8}$ In 1998, the total death rate due to chronic liver disease and cirrhosis was 7.2 per 100,000 people. The age-specific rates were as follows: age 25-34, 1.4; age 35-44, 8.2; age 45-54, 20.3; age 55-64, 25.4; age 65-74, 23.8; age 75-84, 18.6; over 85, 12.6 .

${ }^{9}$ For the U.S. we use age variables for each of 7 categories.
} 
last column repeats the coefficient on alcohol consumption from Table 3. The coefficients on alcohol consumption from the regressions with and without the age variables are similar in most cases. We reject equality of the Table 3 and Table 4 coefficients on alcohol consumption in the cases of Australia, the Czech Republic, Hungary, and the U.S. pre-1950. In the post-WWII U.S. sample the puzzling negative coefficient from the regression without age and sex variables becomes positive. Thus, controlling for the age composition in this way appears reasonable and, in the case of the U.S., important. ${ }^{10}$

A final issue that confronts the use of cirrhosis as a proxy for alcohol consumption is the possibility that the relation between consumption and cirrhosis is not symmetric. Bio-medical evidence suggests that cirrhosis results from a long history of drinking, but it also suggests that the liver can regenerate if drinking stops and that one must be actively drinking to die from cirrhosis. The combination of these facts suggests an asymmetry in the effect of alcohol consumption on cirrhosis: substantial declines in consumption would produce contemporaneous declines in cirrhosis, but substantial increases in consumption, especially from a low level, might take years to yield noticeably higher cirrhosis death rates. As shown below, this issue is important for interpreting the time-series behavior of cirrhosis at the beginning and end of Prohibition.

Table 5 addresses this possibility by regressing cirrhosis on lagged cirrhosis, the age and sex composition variables, and alcohol consumption, separating consumption into two pieces:

\footnotetext{
${ }^{10}$ For the 1941-1997 period, we have compared standard, age-adjusted cirrhosis death rates to rates "adjusted" using our procedure and found a high degree of correlation.
} 
multiplied by an increase dummy and multiplied by a decrease dummy. ${ }^{11}$ For most countries, the coefficient on consumption when consumption is increasing is similar to the coefficient when consumption is decreasing. We can reject equality of the coefficients for Canada and Belgium at the 5\% level and Austria and the full sample of the U.S. at the $10 \%$ level. This outcome is perhaps surprising given the bio-medical evidence discussed above, although some sources suggest that cirrhosis can develop within a short period (Galambos 1979, p. 3). In any case, the regressions do not suggest a strong degree of asymmetry.

We draw the following conclusions from this examination of the data on cirrhosis and alcohol consumption. Time-series fluctuations in consumption exert a positive and significant effect on cirrhosis, although this relation is far from exact. The relation between consumption and cirrhosis appears to involve substantial lags, implying a highly persistent cirrhosis death rate. There is only mild evidence of asymmetry in the effect of alcohol consumption on cirrhosis, although this is difficult to determine with available data. The age and sex composition of the population appear to be important determinants of cirrhosis, at least in the U.S. data.

\section{The Effect of Prohibition on Cirrhosis}

We now examine the relation between Alcohol Prohibition and cirrhosis. We focus in this section on basic facts about the cirrhosis death rate and then discuss the potential role of state prohibitions in explaining these facts. In Section 4 we consider regressions that account for other determinants of cirrhosis death rates.

${ }^{11}$ Specifically, the increase dummy equals one if current consumption is greater than or equal to consumption in the previous period and zero otherwise. The decrease dummy equals one if current consumption is less than last period's consumption and zero otherwise. 


\section{Basic Facts}

Figure 3 presents the cirrhosis death rate for the United States over the period 1900-1997. Cirrhosis was low during the fourteen years of Prohibition compared to periods before or after. The average value over the years 1920-1933 was 7.3 , while the average value in the years 19001919 and 1934-1997 was 11.5. ${ }^{12}$ This simple comparison between the Prohibition and nonProhibition years is the basis for the claim that Prohibition reduced cirrhosis. In particular, many previous analyses have compared cirrhosis between a pre-Prohibition year, such as 1915, and a Prohibition year, such as 1925, and concluded that Prohibition reduced the cirrhosis death rate by almost $50 \%{ }^{13}$

Further examination, however, suggests this conclusion is premature. To begin, there is substantial variation in the cirrhosis death rate outside the Prohibition period (as well as substantial variation in countries without prohibition). This suggests that other factors play a substantial role in causing fluctuations in cirrhosis death rates.

In addition, the timing of the increases and decreases in cirrhosis challenges the view that Prohibition caused the low level of cirrhosis during the 1920s and early 1930s. Figure 4 presents the same data as Figure 3 but for the years 1900-1940, to facilitate examination of the years directly before and after Prohibition. This examination reveals two facts. Cirrhosis does not display a dramatic increase after repeal of Prohibition at the end of 1933. And cirrhosis had

\footnotetext{
12 The $18^{\text {th }}$ Amendment took effect January, 1920; the $21^{\text {st }}$ Amendment repealing Prohibition took effect December, 1933.

13 Edwards et al. (1994) note that "during Prohibition in America, for example, cirrhosis mortality declined by almost 50\% (p. 131)." MacCoun and Reuter (2001) comment that "rates for cirrhosis of the liver fell by 50 percent early in Prohibition and recovered promptly after Repeal in 1933 (p. 161)."
} 
almost reached its low 1920 value by 1919, the year before constitutional Prohibition took effect. ${ }^{14}$ Moreover, cirrhosis started declining slowly in 1908 and then began decreasing more quickly around 1916.

The fact that cirrhosis did not jump upon repeal is inconsistent with an important role for Prohibition in affecting cirrhosis if increased alcohol consumption has a contemporaneous effect on cirrhosis. If, on the other hand, it takes years or decades for alcohol consumption to cause death from cirrhosis, one might expect a substantial lag before any increased consumption following repeal could cause a noticeable increase in cirrhosis. The results above did not provide strong evidence that increases in consumption have a smaller impact on cirrhosis than decreases. Given the uncertainty surrounding the precise relation between consumption and cirrhosis, however, it is difficult to take a strong stand on this particular piece of evidence. The absence of a marked jump in cirrhosis after repeal is not suggestive of a major effect, but this is a test with low power.

The fact that cirrhosis had declined to essentially its minimum level before constitutional Prohibition took effect, and that it had been declining for at least a decade, is more problematic for the view that Prohibition caused the low level of cirrhosis during the 1920s and early 1930s. Indeed, the general downward trend in cirrhosis stops in the very year Prohibition took effect. Thus, a critical issue is understanding the pre-1920 decline in cirrhosis.

\footnotetext{
${ }^{14}$ Thornton (1991) appropriately notes that cirrhosis death rates had begun to decline prior to Prohibition (p. 105n); however, he suggests this decline is due to state prohibitions, wartime
} 


\section{State Prohibitions}

One possible explanation for the pre-1920 decline in cirrhosis is state-level prohibitions. Thirty-two states adopted prohibition laws during the pre-1920 period, and the number of states with such laws increased noticeably during the 1910s. Table 6 shows the states adopting statelevel prohibition in each year over the $1900-1920$ period. The table seems to suggest these prohibitions caused the decrease in cirrhosis during the 1910s since the number of state prohibitions increased substantially around the time cirrhosis decreased.

Several factors, however, cast doubt on the hypothesis that state-level prohibitions caused the pre-1920 decline in cirrhosis. Although the number of states with prohibition was large, these states were predominantly rural, low population states. By 1918, thirty-one states had adopted a prohibition law, but $52.1 \%$ of the population lived in wet states, and the distribution of states that passed prohibition laws before WWI was not random. Of the twenty-six that had prohibition laws, "fourteen were west of the Mississippi. Eight were south of the Ohio and Potomac. Two (Maine and New Hampshire) were in northern, rural New England (Merz 1930, p. 19)." Only two (Michigan and Indiana) were populated, industrial states.

The role of state prohibition is also not compelling because the laws in many states were weak; in particular, they fell far short of bone-dry prohibition (Merz 1930, pp. 20-22). Many states allowed for the importation of certain quantities of alcohol and/or home manufacture. For example, Alabama law allowed any citizen to import two quarts of distilled spirits or two gallons of wine or five gallons of beer every fifteen days. Virginia law allowed importation of one quart of distilled spirits or three gallons of beer or one gallon of wine every thirty days, except for

prohibitions and increased taxes (p. 103). We show below that taxes and state prohibitions play little role in this pre-1920 decline. 
students at a university, college or other school, or minors, or a female not the head of household. Indiana laws stated that it did not intend to interfere with domestic manufacture of wine. Michigan, New Hampshire, Iowa, and North Dakota laws did not prohibit importation for personal use. Mississippi law permitted manufacture of homemade wine. North Carolina allowed importation of one quart of spirits or five gallons of beer every fifteen days. West Virginia permitted manufacture of wine for personal use and importation of one quart of liquor every thirty days. Tennessee permitted manufacture for personal use. South Carolina allowed importation of one quart of liquor every thirty days for medicinal purposes. ${ }^{15}$

Figures 5 and 6 provide an initial look at the possible effect of state prohibition laws by showing state-level data on cirrhosis for two groups of states: those that were wet throughout the pre-1920 period, and those that adopted state prohibition laws at some point during this period. We present only a subset of the states in each category to avoid cluttering the graph; the regression analysis in Section 4 considers the complete set of states.

The figures show that the most dramatic declines in cirrhosis occurred in states that were wet throughout the pre-1920 period, and these states included several of the most populous states (e.g., New York, Pennsylvania, New Jersey). There is some evidence of declines in states that adopted prohibition during this period, but the declines appear smaller on average than the declines in wet states. These figures do not support the hypothesis that state prohibition laws lowered cirrhosis death rates.

${ }^{15}$ Isaac (1965) provides a detailed analysis of the prohibition movement in Tennessee up to the passage of constitutional prohibition. He describes both the legal regime and enforcement as weak during the first few years of state prohibition, 1909-1913, and he suggests that alcohol consumption continued without much interruption in the larger cities. He also describes the legal regime and the degree of enforcement as becoming gradually stricter beginning in 1914, but he suggests that liquor was still widely available at least in the major cities. 
A further suggestive piece of evidence on the effects of state prohibitions comes from a more detailed examination of the data on alcohol consumption and cirrhosis for the pre-1920 period, shown in Figure 7. The key fact is that cirrhosis declined before alcohol consumption declined; indeed, alcohol consumption gives no indication of a decline until 1918, well after the wave of state prohibition adoptions. ${ }^{16}$ Thus, if one examines alcohol consumption, rather than cirrhosis, even the aggregate data suggest little effect of the state prohibitions.

\section{Regression Analysis}

The data presented above raise questions about the role of state prohibitions in causing the cirrhosis decline during 1910s, and they suggest caution in crediting constitutional prohibition for the low level of cirrhosis during the 1920-1933 period. These data, however, do not account for the range of factors that might influence cirrhosis. In this section we present two methods for examining the influence of state and national prohibition while controlling for the effects of other variables.

Regressions with Unconstrained Year Dummies

Our first method of analyzing the impact of these policies is to estimate the equation

$$
c_{i t}=\alpha_{i}+\gamma p_{i t}+\rho c_{i t-1}+\beta_{t}+\varepsilon_{i t}
$$

\footnotetext{
${ }^{16}$ The official data potentially overstate the actual decline in alcohol consumption because the federal laws passed during this period plausibly induced underreporting. For example, the higher tax rates adopted in 1916-1917 might have encouraged home production, and the federal order to close the breweries and distilleries (see below) might have spawned illicit production.
} 
where $c_{i t}$ is the cirrhosis death rate in state $i$ in year $t, \alpha_{i}$ is a fixed effect for state $i, p_{i t}$ is a dummy variable equal to 1 if state $i$ had a state prohibition law in effect in year $t$ and zero otherwise, $\beta_{t}$ is a year dummy for year $t$, and $\varepsilon_{i t}$ is an error term. ${ }^{17}$

This specification allows us to estimate the impact of state prohibitions on cirrhosis while allowing for a general set of aggregate effects. Thus, the year dummies account for any aggregate changes in tax rates, demographics, social attitudes, or other variables that might influence cirrhosis, as well as for Prohibition or pre-1920 anti-alcohol policies (see below). This specification does not account for state-level time-series variation in these variables; in most cases appropriate data are not available. ${ }^{18}$ This approach also fails to identify the separate effects of different aggregate factors, but examination of the year dummies themselves potentially sheds light on the influence of such variables. ${ }^{19}$

Table 7 reports the results of estimating (1) using state-level data on cirrhosis death rates. ${ }^{20}$ The panel is not balanced; in ten states cirrhosis data are available beginning in 1900 while in

17 This regression does not account for the possibility that state prohibition might be endogenous to cirrhosis death rates. One possibility is that states with low or falling death rates were more likely to adopt prohibition. In this case, the regression results overstate the effect of state-level prohibitions. Most prohibition laws were passed in low cirrhosis states.

${ }^{18}$ State-level alcohol taxes are available but awkward to employ because some states used state provision as a way to raise alcohol prices. We have experimented with different specifications of state alcohol policy and found that inclusion of this information has virtually no impact on the results reported here.

${ }^{19}$ In addition to the specifications reported here, we have also estimated regressions that include an interaction term between state prohibition and federal prohibition. These generally yield a positive coefficient on the interaction term and a more negative or less positive coefficient on state prohibitions. The implied impacts of state prohibition are overall extremely similar to those reported in the text.

${ }^{20}$ The dates of the state prohibition laws are from Wickersham (1931) and Distilled Spirits Institute, various issues. 
other states the first year of data varies. The results are weighted by state population, although this makes only a small difference to the results. We consider three different sample periods: 1900-1919, 1900-1950, and 1900-1997. The shorter samples reduce the impact of inconsistencies in measurement of cirrhosis, and the earlier data appear better correlated with alcohol consumption. The longer sample contains more information and is preferable so long as the equation is correctly specified and the data are measured consistently.

The results for 1900-1919 show a positive but insignificant effect of state prohibitions on cirrhosis while the results for 1900-1950 yield a positive and significant effect. The results for 1900-1997 show a negative but insignificant effect of state prohibitions.

To assess the quantitative importance of these results (especially those for the 1900-1997 sample), we use the estimated equations to simulate the path of cirrhosis in the absence of state prohibitions and then calculate the percent decrease in cirrhosis caused by state prohibitions. ${ }^{21}$ These calculations are provided in bottom rows of Table 7. The results using the 1900-1919 and 1900-1950 regressions indicate that state prohibitions raised cirrhosis, consistent with the positive coefficient on state prohibitions. The results using the 1900-1997 estimates indicate that state prohibitions reduced cirrhosis by less than 1\% during the 1910-1920 and 1920-1933 periods, by about $6 \%$ during the $1933-1950$ period, and by $2 \%$ during the $1950-1997$ period.

\footnotetext{
${ }^{21}$ The simulations are computed as follows. For each state, the actual cirrhosis death rate is used for the initial year and any years up to the passage of state prohibition. Once a state has adopted prohibition, the regression coefficients are used to predict the cirrhosis death rate in the absence of the state prohibition. This predicted cirrhosis death rate is then used as the lagged cirrhosis death rate for the next year's prediction. Predicted values are calculated for all years after a state has passed prohibition, even once the prohibition is repealed. The calculated impact is the predicted cirrhosis death rate over the given period less the actual cirrhosis death rate, all divided by the predicted cirrhosis death rate. Thus, the impact for states that did not pass a state prohibition is zero.
} 
Thus, even if one takes the insignificant coefficient from the 1900-1997 regression at face value, it indicates state prohibitions played little role in reducing cirrhosis death rates.

Figures $8 \mathrm{a}$ and $8 \mathrm{~b}$ present the estimated year dummies from the regressions without the interaction term. ${ }^{22}$ The estimates are consistent with the hypothesis that, controlling for state prohibitions and lagged cirrhosis, there are only modest effects of constitutional prohibition. The estimates do suggest that one or more factors caused a large decline in cirrhosis during the last 23 years before the onset of constitutional prohibition, but conditional on this decline, cirrhosis proceeded almost as would have been expected in the absence of Prohibition due to its high degree of autocorrelation.

Regressions with Controls for Aggregate Effects

We now consider regressions of the form

$$
c_{i t}=\alpha_{i}+\gamma p_{i t}+\delta z_{t}+\theta P_{t}+\rho c_{i t-1}+\beta x_{t}+\varepsilon_{i t}
$$

where $z_{t}$ is a dummy variable equal to 1 for the years 1917-1919 and zero otherwise, $P_{t}$ is a measure of national prohibition, $x_{t}$ is other aggregate variables, and $\varepsilon_{i t}$ is an error term. These regressions exclude year dummies.

We include the term $z_{t}$ to account for the possible effects of pre-1920 federal anti-alcohol policies. In February 1917, Congress passed the Reed bone-dry amendment, which forbade interstate shipment of liquor into states that prohibited manufacture and sale, even if the state

${ }^{22}$ The plots from the regressions with the interaction terms are similar. 
allowed importation. (Merz 1930, p. 20). ${ }^{23}$ In August 1917, Congress adopted the Food Control Law, which forbade the manufacture of distilled spirits from any form of foodstuff, and closed the distilleries (Merz 1930, pp. 26-27, 40-41); in September 1918, it closed the breweries as well (Merz 1930, p. 41). Also in September 1918, Congress approved wartime prohibition, although this prohibition did not take effect until July 1, 1919 (Merz 1930, p. 41). The wartime prohibition act contained the first general restriction on sale, providing that after June 30, 1919, no liquor could be sold for beverage purposes except for export (Schmeckebier 1929, pp. 4-5).

We control for tax rates on alcohol by including the real, statutory tax rate on distilled spirits or the real, statutory tax rate on non-beverage distilled spirits. ${ }^{24,25}$ Those caught violating Prohibition were required to pay taxes on the alcohol produced. Thus, an interaction term between Prohibition and the tax rate allows for a differing effect of the tax during Prohibition. Also, distilled spirits produced for non-beverage purposes and taxed at the non-beverage rate were frequently diverted to beverage spirits. $\mathrm{Hu}(1950)$ states that relatively little beverage spirits tax revenue was collected during Prohibition compared to the quantities diverted from non-

${ }^{23}$ In February 1913, Congress had adopted the Webb-Kenyon Law, which prohibited shipments of liquor from wet states into dry states if such shipments were in violation of the dry state law. This did not prohibit all shipments into dry states, since some dry states allowed importation (Merz 1930, p. 14). The law was widely viewed as ineffective, which was one reason for the Reed amendment.

${ }^{24}$ We have also measured the tax rate using the implicit tax rate on all alcoholic beverages. This measure is constructed using data on tax revenues and consumption expenditures. Thus, adequate measures are not available during Prohibition. Using the implicit tax rate leads to estimates that suggest that Prohibition increased consumption. Miron (1997) explains the construction of the tax variables.

${ }^{25}$ Alcoholic substances produced for purposes such as medicine, flavoring extracts, etc. were considered legal non-beverage spirits and taxed at a lower rate. Hu (1950) provides more detail on federal taxation of distilled spirits during this period. 
beverage or industrial uses. This suggests that the non-beverage tax may better capture the tax faced by producers during Prohibition. Estimates of the effect of Prohibition are lower in the non-beverage tax specifications. ${ }^{26,27}$

We employ the U.K. cirrhosis death rate as a measure of social attitudes, since the Temperance movement existed across countries. We control for the level of income using real GNP per capita. We also include but do not report the age and sex composition variables discussed above.

Tables 8 and 9 present results for the 1900-1997 and 1900-1950 periods, respectively. The left half of each table employs a dummy variable to measure Prohibition while the right half employs real enforcement expenditure per capita. ${ }^{28,29}$

The results are consistent across specifications. The coefficient on lagged cirrhosis always enters statistically significantly, in the range of $0.87-0.88$. Thus, cirrhosis is highly persistent, even after controlling for these other factors.

State prohibitions are estimated to have a negative and sometimes statistically significant effect in the 1900-1997 regressions but a positive and statistically significant effect in the 19001950 regressions. The estimated impact is slightly greater than in the regressions with

\footnotetext{
${ }^{26}$ Similar regressions using the real federal tax rate on beer in place of the tax on distilled spirits produce similar but somewhat smaller estimates of the effect of Prohibition.

${ }^{27}$ We have also estimated the regressions including state tax rates on distilled spirits and an indicator variable for whether a state is a control state. The estimates are qualitatively and quantitatively similar.

${ }^{28}$ Including an interaction between state and federal prohibition has little impact on these results.

${ }^{29}$ Miron (1999) discusses the construction of the real enforcement expenditure data.
} 
unconstrained year dummies, presumably because those year dummies account for unmeasured determinants of cirrhosis that correlate with state prohibitions. Since the year dummy approach is the more robust method of estimating the state prohibition effects, we regard those as the more relevant estimates. ${ }^{30}$ In any case, the implied impacts of state prohibitions are similar to those shown in Table 7.

The dummy for 1917-1919 enters significantly in all regressions, with a coefficient in the range -0.27 to -1.7 . Whether this reflects pre-1920 federal anti-alcohol policies cannot be determined from these regressions, but there are reasons to doubt these policies had a major impact. Cirrhosis began declining in 1908, albeit at a slower rate, well before these laws took effect. The Reed amendment (like the earlier Webb-Kenyon law) was designed to facilitate enforcement of state prohibitions, but the evidence presented here suggests these had little effect overall and none in the pre-1920 period. The Food Control Laws did not prevent importation of alcohol or consumption of existing stocks, and wartime prohibition did not take effect until July 1, 1919. Moreover, Congress made no appropriations for enforcement of any of these laws.

Attributing the 1917-1919 decline in cirrhosis to pre-1920 anti-alcohol policies is also problematic because there are other plausible explanations that are not fully accounted for by our regressions. Until 1920, annual estimates of the age composition of the population were based on interpolations of decadal census data without annual data on births, deaths or immigration (Bureau of the Census, 1975). Thus, for the pre-1920 period, our age composition variables plausibly miss important influences on cirrhosis such as the massive decline in immigration rates

${ }^{30}$ Constraining the coefficient on state prohibition to that obtained in the regression with unconstrained year dummies has no significant effect on the coefficient on Prohibition or any of the other variables. 
during the 1910s. In addition, World War I and the flu epidemic of 1918 produced an enormous surge in the death rate (Bureau of the Census, 1975, pp. 58-62), so the population at risk of cirrhosis was likely substantially reduced during the years 1918-1919. Warburton (1932, p. 25) suggests that alcoholic beverages were stockpiled in anticipation of wartime restrictions. And as noted above, the decline in cirrhosis appears to precede the decline in alcohol consumption. Thus, we are skeptical that the pre-1920 decline in cirrhosis is mainly due to anti-alcohol policies, but we cannot rule out that possibility.

The coefficients on constitutional prohibition indicate it reduced cirrhosis. To gauge the magnitude, we simulate the path of cirrhosis in the absence of Prohibition. ${ }^{31}$ The average percent decrease in the cirrhosis death rate during Prohibition relative to the simulated rate is in the bottom row of Tables 8 and 9 . The estimated reductions range from $-20.8 \%$ to $30.9 \%$ with an average reduction across specifications of $12.6 \%$.

The correct interpretation of the cirrhosis data is thus that various factors led to a dramatic decline in cirrhosis between roughly 1908 and 1920, especially during the years 1917-1919. There is no evidence that state prohibitions caused this decline, and it is unclear whether pre1920 federal anti-alcohol policies contributed to the decline. Given the persistence of cirrhosis and the low level it had reached by 1920, however, the continued low level during the 1920-1933 period does not suggest a major effect of constitutional prohibition in causing this low level. Instead, our estimates suggest constitutional prohibition reduced cirrhosis by $10-20 \%$.

\footnotetext{
${ }^{31}$ We use actual cirrhosis death rates for the years prior to Prohibition. Then, we estimate the predicted cirrhosis death rate in the absence of prohibition using the estimated regression coefficients. The predicted rate is then used as the lagged cirrhosis death rate for the next year's prediction. The estimated impact is the simulated cirrhosis death rate less the actual cirrhosis death rate all divided by the simulated cirrhosis death rate.
} 


\section{Discussion}

We conclude by relating our results to the literature on the price-elasticity of the demand for alcohol. That literature offers a broad range of elasticity estimates, from virtually zero for certain population subgroups to well in excess of -1.0 overall. ${ }^{32}$ If the true elasticity is in the middle of this range, the small response of cirrhosis to Prohibition is surprising given the conventional view that alcohol prices rose substantially during Prohibition. The estimates in Table 4 above indicate an elasticity of cirrhosis with respect to alcohol consumption of $0.4-0.7$, and Thornton (1991) suggests that alcohol prices rose by about 500\%. This implies that cirrhosis should have fallen to almost nothing, rather than declining $10-20 \%$ as estimated above.

One possible reconciliation is that the relevant elasticity is in fact quite low. The proxy for alcohol consumption considered here is plausibly a better measure of heavy consumption than of moderate consumption. Theory does not suggest that heavy or addictive consumption is necessarily inelastic (Becker and Murphy 1988), but there is evidence from micro data suggesting that heavy consumption of alcohol is in fact virtually price inelastic (Manning, Blumberg, and Moulton 1995).

A second possible reconciliation is that the standard view about alcohol prices is inaccurate. The conventional wisdom is based on data in Warburton (1932) and Fisher (1928, 1930); reexamination of these data suggests a more nuanced picture.

32 See Phelps and Leung (1991) for a detailed review and Chaloupka, Grossman, Becker and Murphy (1993), Chaloupka and Grossman (1994), Manning, Blumberg, and Moulton (1995), Moore and Cook (1995), Chaloupka and Wechsler (1996), Chaloupka and Laixuthai (1997), Grossman, Chaloupka, and Sirtalan (1998), and Williams, Chaloupka, and Wechsler (2002) for more recent work. 
A first problem with the standard view is that it neglects the behavior of the overall price level. Warburton's data compare prices between 1911-1915 and 1926-1930, while Fisher's compare prices between 1916 and 1928. Both authors examine the behavior of nominal prices, yet the price level increased by approximately 75 per cent between these two periods (Bureau of the Census (1975), p. 211). Thus, the raw data presented by Warburton and Fisher overstate the increase in the relative price of alcohol.

In addition, Warburton presents a broad range of prices for the Prohibition period, and the lowest prices reported suggest that, even ignoring inflation, some alcoholic beverage prices fell relative to the pre-Prohibition period. This does not prove consumers paid less on average for alcohol, but they faced an incentive to buy at the lowest prices and then stockpile the quantities purchased. The available data do not allow computation of the average price actually paid, and the extremely high prices reported in many cases by both Warburton and Fisher allow for the possibility that the average price in fact rose. But the magnitude of this rise is undoubtedly less than they asserted, and it is possible prices failed to rise substantially overall. If prices did not increase very much, there is no puzzle in the failure of consumption to fall substantially.

This last "explanation" raises the question of why prices would not have risen more strongly. One possibility is that because black market suppliers faced low marginal costs of evading alcohol taxes and cost-increasing regulation, the net effect of prohibition on costs was modest (Miron 2003).

A second hypothesis is that Prohibition had little chance of being effective because of the numerous avenues for evasion (Merz 1930, pp.65-71). Under Prohibition, physicians, druggists and manufacturers of proprietary medicines could receive licenses to prescribe and dispense 
liquor for "medicinal" purposes. The production of beer for the purpose of making near beer remained legal, as did the production of industrial alcohol. ${ }^{33}$ Both exceptions to Prohibition allowed for substantial diversion to consumption. Smuggling across the vast borders of the U.S. provided another way to circumvent Prohibition. And perhaps most importantly, home production and small scale production of alcohol proliferated, thereby straining even the most vigorous enforcement efforts.

A third possibility is that Prohibition created a forbidden fruit effect, thereby shifting preferences for alcohol and partially offsetting the depressing effect on demand of higher prices. This hypothesis receives anecdotal support in some contexts, and accounts of drinking behavior during Prohibition are consistent with such an effect (e.g., the term "roaring 20s"). Without more detailed evidence, however, one cannot interpret the results here as a strong indication of such an effect.

Determining which of the above hypotheses is the best interpretation of the factual results in this paper is not possible without further research. The implications of any interpretation, however, are important for policy toward a wide variety of currently prohibited activities.

${ }^{33}$ The method of producing near beer is to make real beer and then remove most of the alcohol. 


\section{References}

Aaron, Paul and David Musto (1981), "Temperance and Prohibition in America: A Historical Overview," in Alcohol and Public Policy: Beyond the Shadow of Prohibition, eds. Mark H. Moore and Dean R. Gerstein, 127-181.

Anderson, R.N. and H.M. Rosenberg (1998), "Age Standardization of Death Rates: Implementation of the Year 2000 Standard," National Vital Statistics Reports, 47(3), Hyattsville, MD: National Center for Health Statistics.

Becker, Gary S. and Kevin M. Murphy (1988), “A Theory of Rational Addiction," Journal of Political Economy, 96, 675-700.

Berkow, Robert, ed. (1992), The Merck Manual. 16th ed. Rahway, N.J.: Merck and Co., Inc.

Brewers Association of Canada (1997), International Survey -- Alcoholic Beverage Taxation and Control, 9 th ed. November.

Bureau of the Census (1975), Historical Statistics of the United States, Washington: USGPO.

Chaloupka, Frank J., Michael Grossman, Gary S. Becker, and Kevin M. Murphy (1993), "Alcohol Addiction: An Econometric Analysis," manuscript, University of Illinois at Chicago.

Chaloupka, Frank J. and Michael Grossman (1994), "Drinking and Addiction? Evidence from the First National Health and Nutrition Examination Survey," manuscript, University of Illinois at Chicago.

Chaloupka, Frank J. and Adit Laixuthai (1997), "Do Youths Substitute Alcohol and Marijuana? Some Econometric Evidence," Eastern Economic Journal, 23(3), 253-276.

Chaloupka, Frank J. and Henry Wechsler (1996), "Binge Drinking in College: The Impact of Price, Availability, and Alcohol Control Policies," Contemporary Economic Policy, 14, 112-124.

Cook, Philip J. (1981), "The Effect of Liquor Taxes on Drinking, Cirrhosis, and Auto Accidents," in M.H. Moore and D.R. Gerstein, eds., Alcohol and Public Policy: Beyond the Shadow of Prohibition, National Academy Press, Washington, 255-85.

Cook, Philip J. and Tauchen, George. (1982), "The Effect of Liquor Taxes on Heavy Drinking," Bell Journal of Economics, 13, 379-390.

Distilled Spirits Institute (various years), Annual Statistical Review, The Distilled Spirits Industry, Research and Statistics Division: Washington, DC.

Edwards, Griffith et. al. (1994), Alcohol Policy and the Public Good, New York: Oxford University Press Inc.

Fisher, Irving (1928), Prohibition Still at Its Worst, New York: Alcohol Information Committee.

Fisher, Irving (1930), The Noble Experiment, New York: Alcohol Information Committee.

Galambos, John T. (1979), Cirrhosis, vol. XVII in the series Major Problems in Internal Medicine. 
Grossman, Michael, Frank J. Chaloupka, and Ismail Sirtalan (1998), "An Empirical Analysis of Alcohol Addiction: Results from the Monitoring the Future Panels," Economic Inquiry, 36(1), 39-48.

Hu, Tun Yuan (1950), The Liquor Tax in the United States: 1791-1947. A History of the Internal Revenue Taxes Imposed on Distilled Spirits by the Federal Government, New York: Columbia University.

Isaac, Paul E. (1965), Prohibition and Politics: Turbulent Decades in Tennessee, 1885-1920, Knoxville: The University of Tennessee Press.

MacCoun, Robert J. and Peter Reuter (2001), Drug War Heresies: Learning from Other Vices, Times and Places, Cambridge: Cambridge University Press.

Manning, Willard G., Linda Blumberg, and Lawrence H. Moulton (1995), "The Demands for Alcohol: The Differential Response to Price," Journal of Health Economics, 14, 2(June), $123-48$.

Merz, Charles (1930), The Dry Decade, Garden City, NY: Doubleday, Doran and Co.

Miron, Jeffrey A. (1996), "Some Estimates of Annual Alcohol Consumption Per Capita, 18701991," ISP Discussion Paper \#69, Department of Economics, Boston University.

Miron, Jeffrey A. (1997), "The Effect of Alcohol Prohibition on Alcohol Consumption," NBER WP \#7130.

Miron, Jeffrey A. (1999), "Violence and the U.S. Prohibitions of Drugs and Alcohol," American Law and Economics Review, 1(1-2), 78-114.

Miron, Jeffrey A. (2003), "Do Prohibitions Raise Prices: Evidence from the Markets for Cocaine and Heroin," Review of Economics and Statistics, forthcoming.

Moore, Michael J. and Philip J. Cook (1995), "Habit and Heterogeneity in the Youthful Demand for Alcohol,” NBER WP \#5152.

Moore, Mark H. and Dean R. Gerstein, eds. (1981), Alcohol and Public Policy: Beyond the Shadow of Prohibition, Washington, D.C.: National Academy Press.

Musto, David F. (1996), “Alcohol in American History," Scientific American, April, 78-83.

Newey, Whitney and Kenneth West (1987), "A Simple, Positive Definite, Heteroskedasticity and Autocorrelation Consistent Covariance Matrix," Econometrica, 55, 703-8.

Phelps, Charles E. and Sui-Fai Leung (1991), "My Kingdom for a Drink? A Review of Estimates of the Price Sensitivity of Demand for Alcoholic Beverages," manuscript, University of Rochester.

Schmeckebier, Laurence F. (1929), The Bureau of Prohibition: Its History, Activities, and Organization, The Brookings Institution: Washington.

Thornton, Mark (1991), The Economics of Prohibition, University of Utah Press: Salt Lake City.

Warburton, Clark (1932), The Economic Results of Prohibition, Columbia University Press: New York. 
Wickersham, George W. (1931), Enforcement of the Prohibition Laws, v.5, U.S. Government Printing Office: Washington.

Williams, Jenny, Frank J. Chaloupka, and Henry Wechsler (2002), "Are there Differential Effects of Price and Policy on College Students' Drinking Intensity?," NBER WP\#8702.

World Health Organization, World Health Statistics Annual, various years.

Yoon, Young-Hee, Hsiao-ye Yi, Bridget F. Grant and Mary C. Dufour (2001), "Liver Cirrhosis Mortality in the United States, 1970-1998," Surveillance Report \#57, U.S. Department of Health and Human Services, National Institute on Alcohol Abuse and Alcoholism, Washington, D.C. (available at http://www.niaaa.nih.gov/publications/Cirr98.pdf). 
Table 1: Regressions of Cirrhosis on Alcohol Consumption

\begin{tabular}{|c|c|c|c|c|c|}
\hline Country & Sample Period & constant & $\mathrm{A}_{t}$ & $\mathrm{R}^{2}$ & D-W \\
\hline Australia & $1958-95$ & $\begin{array}{l}-2.577 \\
(5.38)\end{array}$ & $\begin{array}{l}1.111 \\
(19.08)\end{array}$ & 0.93 & 0.941 \\
\hline Austria & $1958-90$ & $\begin{array}{l}1.546 \\
(0.43)\end{array}$ & $\begin{array}{l}2.549 \\
(7.18)\end{array}$ & 0.65 & 0.680 \\
\hline Belgium & $1958-93$ & $\begin{array}{l}3.185 \\
(6.29)\end{array}$ & $\begin{array}{l}0.978 \\
(15.08)\end{array}$ & 0.84 & 1.277 \\
\hline Czech & $1958-72$ & $\begin{array}{l}-3.037 \\
(2.51)\end{array}$ & $\begin{array}{l}2.140 \\
(11.95)\end{array}$ & 0.92 & 1.327 \\
\hline Denmark & $1958-95$ & $\begin{array}{l}3.712 \\
(5.41)\end{array}$ & $\begin{array}{l}0.851 \\
(8.63)\end{array}$ & 0.75 & 0.551 \\
\hline Hungary & $1958-72$ & $\begin{array}{l}-0.483 \\
(0.91)\end{array}$ & $\begin{array}{l}1.463 \\
(21.95)\end{array}$ & 0.9 & 2.086 \\
\hline Italy & $1958-95$ & $\begin{array}{l}23.692 \\
(9.77)\end{array}$ & $\begin{array}{l}0.325 \\
(1.19)\end{array}$ & 0.01 & 0.042 \\
\hline Netherlands & $1958-95$ & $\begin{array}{l}2.812 \\
(15.58)\end{array}$ & $\begin{array}{l}0.259 \\
(9.79)\end{array}$ & 0.78 & 1.453 \\
\hline Norway & $1958-95$ & $\begin{array}{l}1.015 \\
(1.66)\end{array}$ & $\begin{array}{l}1.041 \\
(5.27)\end{array}$ & 0.46 & 0.933 \\
\hline Sweden & $1958-95$ & $\begin{array}{l}-6.701 \\
(3.74)\end{array}$ & $\begin{array}{l}2.805 \\
(7.66)\end{array}$ & 0.67 & 0.260 \\
\hline Canada & $1922-56,1958-95$ & $\begin{array}{l}1.053 \\
(3.48)\end{array}$ & $\begin{array}{l}1.082 \\
(16.33)\end{array}$ & 0.9 & 0.332 \\
\hline U.K. & $1952-1995$ & $\begin{array}{l}-0.737 \\
(1.81)\end{array}$ & $\begin{array}{l}0.810 \\
(9.68)\end{array}$ & 0.78 & 0.143 \\
\hline Ireland & $1933-37,1953-94$ & $\begin{array}{l}1.759 \\
(7.53)\end{array}$ & $\begin{array}{l}0.228 \\
(5.40)\end{array}$ & 0.47 & 1.065 \\
\hline France & $1925-35,1946-94$ & $\begin{array}{l}2.408 \\
(0.48)\end{array}$ & $\begin{array}{l}1.502 \\
(4.95)\end{array}$ & 0.38 & 0.303 \\
\hline Finland & 1958-1995 & $\begin{array}{l}-0.188 \\
(0.31)\end{array}$ & $\begin{array}{l}1.184 \\
(8.09)\end{array}$ & 0.7 & 0.136 \\
\hline U.S. & $1900-19,1935-50$ & $\begin{array}{l}0.942 \\
(0.81)\end{array}$ & $\begin{array}{l}1.847 \\
(8.24)\end{array}$ & 0.65 & 0.403 \\
\hline U.S. & 1950-1995 & $\begin{array}{l}7.724 \\
(5.58)\end{array}$ & $\begin{array}{l}0.647 \\
(2.95)\end{array}$ & 0.14 & 0.047 \\
\hline U.S. & $1900-19,1934-95$ & $\begin{array}{l}5.500 \\
(5.86)\end{array}$ & $\begin{array}{l}0.996 \\
(5.95)\end{array}$ & 0.36 & 0.090 \\
\hline
\end{tabular}

Newey-West (1987) t-statistics in parentheses. 
Table 2: Regressions of Cirrhosis on Alcohol Consumption and Lagged Consumption

\begin{tabular}{|c|c|c|c|c|c|c|}
\hline$\underline{\text { Country }}$ & Sample Period & constant & $\mathrm{A}_{t}$ & $\mathrm{~A}_{t-1}$ & $\left.\underline{A}_{t}\right]+\underline{\beta}_{2}\left[\mathrm{~A}_{t-1}\right]$ & $\mathrm{R}^{2}$ \\
\hline Australia & $1958-95$ & $\begin{array}{l}-2.600 \\
(-5.32)\end{array}$ & $\begin{array}{l}1.319 \\
(4.17)\end{array}$ & $\begin{array}{l}-0.206 \\
(-0.69)\end{array}$ & $\begin{array}{l}1.113 \\
(19.02)\end{array}$ & 0.94 \\
\hline Austria & $1958-90$ & $\begin{array}{l}2.547 \\
(0.77)\end{array}$ & $\begin{array}{l}-0.260 \\
(-0.24)\end{array}$ & $\begin{array}{l}2.744 \\
(2.76)\end{array}$ & $\begin{array}{l}2.485 \\
(7.56)\end{array}$ & 0.78 \\
\hline Belgium & $1958-93$ & $\begin{array}{l}3.162 \\
(5.96)\end{array}$ & $\begin{array}{l}1.062 \\
(3.37)\end{array}$ & $\begin{array}{l}-0.082 \\
(-0.28)\end{array}$ & $\begin{array}{l}0.980 \\
(14.76)\end{array}$ & 0.90 \\
\hline Czech & $1958-72$ & $\begin{array}{l}-3.032 \\
(-2.67)\end{array}$ & $\begin{array}{l}0.933 \\
(1.11)\end{array}$ & $\begin{array}{l}1.255 \\
(1.58)\end{array}$ & $\begin{array}{l}2.188 \\
(13.77)\end{array}$ & 0.94 \\
\hline Denmark & $1958-95$ & $\begin{array}{l}4.078 \\
(5.65)\end{array}$ & $\begin{array}{l}-0.193 \\
(-0.25)\end{array}$ & $\begin{array}{l}1.021 \\
(1.37)\end{array}$ & $\begin{array}{l}0.828 \\
(8.66)\end{array}$ & 0.86 \\
\hline Hungary & $1958-72$ & $\begin{array}{l}-0.682 \\
(-0.85)\end{array}$ & $\begin{array}{l}1.093 \\
(2.69)\end{array}$ & $\begin{array}{l}0.413 \\
(0.86)\end{array}$ & $\begin{array}{l}1.505 \\
(13.23)\end{array}$ & 0.91 \\
\hline Italy & $1958-95$ & $\begin{array}{l}16.890 \\
(6.19)\end{array}$ & $\begin{array}{l}-5.240 \\
(-2.55)\end{array}$ & $\begin{array}{l}6.070 \\
(2.86)\end{array}$ & $\begin{array}{l}0.830 \\
(3.62)\end{array}$ & 0.92 \\
\hline Netherlands & $1958-95$ & $\begin{array}{l}2.918 \\
(16.12)\end{array}$ & $\begin{array}{l}-0.045 \\
(-0.31)\end{array}$ & $\begin{array}{l}0.295 \\
(2.09)\end{array}$ & $\begin{array}{l}0.250 \\
(9.86)\end{array}$ & 0.80 \\
\hline Norway & $1958-95$ & $\begin{array}{l}1.024 \\
(1.61)\end{array}$ & $\begin{array}{l}0.922 \\
(1.34)\end{array}$ & $\begin{array}{l}0.118 \\
(0.21)\end{array}$ & $\begin{array}{l}1.040 \\
(5.13)\end{array}$ & 0.52 \\
\hline Sweden & $1958-95$ & $\begin{array}{l}-6.737 \\
(-3.72)\end{array}$ & $\begin{array}{l}0.147 \\
(0.15)\end{array}$ & $\begin{array}{l}2.680 \\
(2.51)\end{array}$ & $\begin{array}{l}2.827 \\
(7.77)\end{array}$ & 0.85 \\
\hline Canada & $1922-56,1958-95$ & $\begin{array}{l}0.994 \\
(2.99)\end{array}$ & $\begin{array}{l}1.462 \\
(3.23)\end{array}$ & $\begin{array}{l}-0.374 \\
(-0.89)\end{array}$ & $\begin{array}{l}1.088 \\
(16.03)\end{array}$ & 0.90 \\
\hline U.K. & $1952-1995$ & $\begin{array}{l}-0.652 \\
(-1.79)\end{array}$ & $\begin{array}{l}-0.394 \\
(-0.91)\end{array}$ & $\begin{array}{l}1.205 \\
(2.6)\end{array}$ & $\begin{array}{l}0.812 \\
(10.4)\end{array}$ & 0.93 \\
\hline Ireland & $1933-37,1953-94$ & $\begin{array}{l}1.707 \\
(6.55)\end{array}$ & $\begin{array}{l}0.283 \\
(1.3)\end{array}$ & $\begin{array}{l}-0.047 \\
(-0.22)\end{array}$ & $\begin{array}{l}0.236 \\
(5.09)\end{array}$ & 0.48 \\
\hline France & $1925-35,1946-94$ & $\begin{array}{l}3.276 \\
(0.63)\end{array}$ & $\begin{array}{l}0.529 \\
(0.4)\end{array}$ & $\begin{array}{l}0.929 \\
(0.69)\end{array}$ & $\begin{array}{l}1.458 \\
(4.62)\end{array}$ & 0.57 \\
\hline Finland & $1958-1995$ & $\begin{array}{l}0.216 \\
(0.47)\end{array}$ & $\begin{array}{l}-0.991 \\
(-1.16)\end{array}$ & $\begin{array}{l}2.147 \\
(2.42)\end{array}$ & $\begin{array}{l}1.156 \\
(9.39)\end{array}$ & 0.90 \\
\hline U.S. & $1900-19,1935-50$ & $\begin{array}{l}0.740 \\
(0.60)\end{array}$ & $\begin{array}{l}1.522 \\
(4.68)\end{array}$ & $\begin{array}{l}0.355 \\
(1.29)\end{array}$ & $\begin{array}{l}1.877 \\
(7.93)\end{array}$ & 0.92 \\
\hline U.S. & 1950-1995 & $\begin{array}{l}7.773 \\
(6.87)\end{array}$ & $\begin{array}{l}5.599 \\
(4.65)\end{array}$ & $\begin{array}{l}-4.975 \\
(-4.22)\end{array}$ & $\begin{array}{l}0.624 \\
(3.53)\end{array}$ & 0.39 \\
\hline U.S. & $1900-19,1934-95$ & $\begin{array}{l}5.425 \\
(4.87)\end{array}$ & $\begin{array}{l}1.625 \\
(3.88)\end{array}$ & $\begin{array}{l}-0.623 \\
(-1.41)\end{array}$ & $\begin{array}{l}1.002 \\
(5.26)\end{array}$ & 0.50 \\
\hline
\end{tabular}

Newey-West (1987) t-statistics in parentheses. 
Table 3: Regressions of Cirrhosis on Lagged Cirrhosis and Alcohol Consumption

\begin{tabular}{|c|c|c|c|c|c|}
\hline Country & Sample Period & constant & $\mathrm{C}_{\mathrm{t}-1}$ & $\mathrm{~A}_{t}$ & $\mathrm{R}^{2}$ \\
\hline Australia & $1958-95$ & $\begin{array}{l}-1.902 \\
(-2.64)\end{array}$ & $\begin{array}{l}0.304 \\
(1.61)\end{array}$ & $\begin{array}{l}0.786 \\
(3.39)\end{array}$ & 0.94 \\
\hline Austria & $1958-90$ & $\begin{array}{l}4.333 \\
(1.57)\end{array}$ & $\begin{array}{l}0.730 \\
(10.4)\end{array}$ & $\begin{array}{l}0.339 \\
(1.1)\end{array}$ & 0.85 \\
\hline Belgium & $1958-93$ & $\begin{array}{l}2.364 \\
(3.17)\end{array}$ & $\begin{array}{l}0.448 \\
(2.23)\end{array}$ & $\begin{array}{l}0.476 \\
(2.2)\end{array}$ & 0.85 \\
\hline Czech & $1958-72$ & $\begin{array}{l}-2.548 \\
(-2.34)\end{array}$ & $\begin{array}{l}0.567 \\
(2.05)\end{array}$ & $\begin{array}{l}1.151 \\
(2.02)\end{array}$ & 0.96 \\
\hline Denmark & $1958-95$ & $\begin{array}{l}1.064 \\
(1.72)\end{array}$ & $\begin{array}{l}0.729 \\
(5.77)\end{array}$ & $\begin{array}{l}0.237 \\
(2.18)\end{array}$ & 0.88 \\
\hline Hungary & $1958-72$ & $\begin{array}{l}-0.504 \\
(-0.73)\end{array}$ & $\begin{array}{l}0.163 \\
(0.54)\end{array}$ & $\begin{array}{l}1.245 \\
(2.95)\end{array}$ & 0.9 \\
\hline Italy & $1958-95$ & $\begin{array}{l}-1.099 \\
(-1.03)\end{array}$ & $\begin{array}{l}0.910 \\
(44.29)\end{array}$ & $\begin{array}{l}0.321 \\
(4.53)\end{array}$ & 0.98 \\
\hline Netherlands & $1958-95$ & $\begin{array}{l}2.008 \\
(4.64)\end{array}$ & $\begin{array}{l}0.301 \\
(2.49)\end{array}$ & $\begin{array}{l}0.177 \\
(5.64)\end{array}$ & 0.78 \\
\hline Norway & $1958-95$ & $\begin{array}{l}0.322 \\
(0.73)\end{array}$ & $\begin{array}{l}0.493 \\
(4.92)\end{array}$ & $\begin{array}{l}0.579 \\
(3.52)\end{array}$ & 0.61 \\
\hline Sweden & $1958-95$ & $\begin{array}{l}-1.944 \\
(-1.61)\end{array}$ & $\begin{array}{l}0.792 \\
(9.58)\end{array}$ & $\begin{array}{l}0.692 \\
(2.23)\end{array}$ & 0.93 \\
\hline Canada & $1922-56,1958-95$ & $\begin{array}{l}0.260 \\
(1.84)\end{array}$ & $\begin{array}{l}0.850 \\
(13.65)\end{array}$ & $\begin{array}{l}0.151 \\
(2.43)\end{array}$ & 0.97 \\
\hline U.K. & $1952-1995$ & $\begin{array}{l}-0.228 \\
(-2.44)\end{array}$ & $\begin{array}{l}0.969 \\
(12.29)\end{array}$ & $\begin{array}{l}0.077 \\
(1.5)\end{array}$ & 0.98 \\
\hline Ireland & $1933-37,1953-94$ & $\begin{array}{l}1.073 \\
(4.26)\end{array}$ & $\begin{array}{l}0.437 \\
(3.21)\end{array}$ & $\begin{array}{l}0.120 \\
(2.74)\end{array}$ & 0.57 \\
\hline France & $1925-35,1946-94$ & $\begin{array}{l}-1.919 \\
(-0.95)\end{array}$ & $\begin{array}{l}0.790 \\
(6.01)\end{array}$ & $\begin{array}{l}0.461 \\
(3.29)\end{array}$ & 0.82 \\
\hline Finland & 1958-1995 & $\begin{array}{l}-0.238 \\
(-1.56)\end{array}$ & $\begin{array}{l}0.893 \\
(13.6)\end{array}$ & $\begin{array}{l}0.198 \\
(2.57)\end{array}$ & 0.97 \\
\hline U.S. & $1900-19,1935-50$ & $\begin{array}{l}-0.266 \\
(-0.44)\end{array}$ & $\begin{array}{l}0.812 \\
(10.65)\end{array}$ & $\begin{array}{l}0.413 \\
(2.14)\end{array}$ & 0.92 \\
\hline U.S. & 1950-1995 & $\begin{array}{l}1.155 \\
(-3.03)\end{array}$ & $\begin{array}{l}1.042 \\
(35.54)\end{array}$ & $\begin{array}{l}-0.246 \\
(4.59)\end{array}$ & 0.97 \\
\hline U.S. & $1900-19,1934-95$ & $\begin{array}{l}0.431 \\
(-1.16)\end{array}$ & $\begin{array}{l}0.984 \\
(27.52)\end{array}$ & $\begin{array}{l}-0.045 \\
(0.58)\end{array}$ & 0.94 \\
\hline
\end{tabular}

Newey-West (1987) t-statistics in parentheses. 
Table 4: Regressions of Cirrhosis on Alcohol Consumption and Age and Sex Variables

\begin{tabular}{|c|c|c|c|c|c|c|}
\hline Country & Sample Period & constant & $\mathrm{C}_{\mathrm{t}-1}$ & $\mathrm{~A}_{\mathrm{t}}$ & $\begin{array}{c}\text { Table } 3 \\
\mathrm{~A}_{\mathrm{t}}\end{array}$ & $\mathrm{R}^{2}$ \\
\hline Australia & $1958-95$ & $\begin{array}{l}652.20 \\
(75.02)\end{array}$ & $\begin{array}{l}-0.305 \\
(1.95)\end{array}$ & $\begin{array}{l}0.849 \\
(2.11)\end{array}$ & 0.786 & 0.98 \\
\hline Austria & $1958-90$ & $\begin{array}{l}-802.77 \\
(12.16)\end{array}$ & $\begin{array}{l}0.235 \\
(1.42)\end{array}$ & $\begin{array}{l}-0.538 \\
(0.73)\end{array}$ & 0.339 & 0.92 \\
\hline Belgium & $1958-93$ & $\begin{array}{l}32713.2 \\
(1420.91)\end{array}$ & $\begin{array}{l}0.049 \\
(0.34)\end{array}$ & $\begin{array}{l}1.054 \\
(5.16)\end{array}$ & 0.476 & 0.92 \\
\hline Czech & $1958-72$ & $\begin{array}{l}176246.2 \\
(3867.83)\end{array}$ & $\begin{array}{l}-0.635 \\
(1.78)\end{array}$ & $\begin{array}{l}0.378 \\
(0.61)\end{array}$ & 1.151 & 0.99 \\
\hline Denmark & $1958-95$ & $\begin{array}{l}-50845.91 \\
(1274.08)\end{array}$ & $\begin{array}{l}0.008 \\
(0.05)\end{array}$ & $\begin{array}{l}-0.121 \\
(0.25)\end{array}$ & 0.237 & 0.94 \\
\hline Hungary & $1958-72$ & $\begin{array}{l}-629391.34 \\
(2426.22)\end{array}$ & $\begin{array}{l}-0.507 \\
(1.25)\end{array}$ & $\begin{array}{l}-0.169 \\
(0.23)\end{array}$ & 1.245 & 0.97 \\
\hline Italy & $1958-95$ & $\begin{array}{l}369.25 \\
(0.11)\end{array}$ & $\begin{array}{l}0.842 \\
(11.05)\end{array}$ & $\begin{array}{l}0.020 \\
(0.06)\end{array}$ & 0.321 & 0.98 \\
\hline Norway & $1958-95$ & $\begin{array}{l}-8736.59 \\
(156.73)\end{array}$ & $\begin{array}{l}-0.200 \\
(0.91)\end{array}$ & $\begin{array}{l}1.952 \\
(2.91)\end{array}$ & 0.579 & 0.78 \\
\hline Sweden & $1958-95$ & $\begin{array}{l}-13044.33 \\
(376.22)\end{array}$ & $\begin{array}{l}0.265 \\
(2.16)\end{array}$ & $\begin{array}{l}1.559 \\
(3.67)\end{array}$ & 0.692 & 0.98 \\
\hline Canada & $1922-56,1958-95$ & $\begin{array}{l}-3248.65 \\
(435.82)\end{array}$ & $\begin{array}{l}0.067 \\
(0.48)\end{array}$ & $\begin{array}{l}1.000 \\
(2.92)\end{array}$ & 0.151 & 0.99 \\
\hline U.K. & $1952-1995$ & $\begin{array}{l}-441.43 \\
(0.62)\end{array}$ & $\begin{array}{l}0.222 \\
(1.07)\end{array}$ & $\begin{array}{l}0.260 \\
(2.33)\end{array}$ & 0.077 & 0.99 \\
\hline Ireland & $1933-37,1953-94$ & $\begin{array}{l}-848.78 \\
(34.06)\end{array}$ & $\begin{array}{l}-0.352 \\
(2.58)\end{array}$ & $\begin{array}{l}0.322 \\
(1.32)\end{array}$ & 0.120 & 0.83 \\
\hline France & $1925-35,1946-94$ & $\begin{array}{l}-42195.35 \\
(427.90)\end{array}$ & $\begin{array}{l}0.508 \\
(2.20)\end{array}$ & $\begin{array}{l}-0.939 \\
(0.70)\end{array}$ & 0.461 & 0.87 \\
\hline Finland & $1958-1995$ & $\begin{array}{l}17902.24 \\
(914.36)\end{array}$ & $\begin{array}{l}0.218 \\
(1.59)\end{array}$ & $\begin{array}{l}1.199 \\
(5.27)\end{array}$ & 0.198 & 0.99 \\
\hline U.S. & $1900-19,1935-50$ & $\begin{array}{l}89.605 \\
(2.98)\end{array}$ & $\begin{array}{l}0.035 \\
(0.18)\end{array}$ & $\begin{array}{l}0.828 \\
(4.10)\end{array}$ & 0.413 & 0.98 \\
\hline U.S. & $1950-1995$ & $\begin{array}{l}83.65 \\
(0.82)\end{array}$ & $\begin{array}{l}0.519 \\
(3.17)\end{array}$ & $\begin{array}{l}0.412 \\
(1.09)\end{array}$ & -0.246 & 0.98 \\
\hline U.S. & $1900-19,1934-95$ & $\begin{array}{l}2.67 \\
(0.13)\end{array}$ & $\begin{array}{l}0.631 \\
(3.62)\end{array}$ & $\begin{array}{l}0.454 \\
(1.74)\end{array}$ & -0.045 & 0.96 \\
\hline
\end{tabular}

Newey-West (1987) t-statistics in parentheses.

Coefficients on age and sex variables suppressed. For all but the U.S., the age variables used are the percentage of the population aged 15-19, 20-24, 25-29, 30-34, 35-39, 40-44, 45-49, 50-54, 55-59, 60-64, and 65 and over (the percentage under 15 is omitted). For the U.S., the age variables used are the percentage of the population aged 5-14, 15-24, 25-34, 35-44, 45-54, 55-64, and 65 and over (the percentage $0-4$ is omitted). 
Table 5: Regressions of Cirrhosis on Lagged Cirrhosis and Alcohol Consumption by Increasing/Decreasing, Age and Sex Variables Included

\begin{tabular}{|c|c|c|c|c|c|c|c|}
\hline untry & Sample Period & constant & cirrhosis & $\mathrm{A}_{t} * \operatorname{Inc}$ & $\mathrm{A}_{t}^{*} \mathrm{Dec}$ & $\begin{array}{l}\text { Test for } \\
\mathrm{A}_{t}^{*} \text { Inc }=\end{array}$ & $\mathrm{R}^{2}$ \\
\hline Australia & $1958-95$ & $\begin{array}{l}1232.45 \\
(127.78)\end{array}$ & & $\begin{array}{l}0.699 \\
(1.60)\end{array}$ & & $\begin{array}{l}2.54 \\
0.1232\end{array}$ & 0.98 \\
\hline Austria & $1958-90$ & $\begin{array}{l}5754.00 \\
(2.27)\end{array}$ & $\begin{array}{l}0.235 \\
(1.96)\end{array}$ & $\begin{array}{l}-0.194 \\
(2.87)\end{array}$ & $\begin{array}{l}-0.110 \\
(1.46)\end{array}$ & $\begin{array}{l}3.78 \\
0.0629\end{array}$ & 0.92 \\
\hline Belgium & $1958-93$ & $\begin{array}{l}39889.94 \\
(1799.63)\end{array}$ & & & & $\begin{array}{l}4.7 \\
0.0408\end{array}$ & 0.92 \\
\hline Czech & $1958-72$ & $\begin{array}{l}5340.79 \\
(0.92)\end{array}$ & & & & $\begin{array}{l}0.21 \\
0.6487\end{array}$ & 0.94 \\
\hline Denmark & $1958-95$ & $\begin{array}{l}-47193.84 \\
(1038.95)\end{array}$ & & & $\begin{array}{l}0 \\
\text { 2) }\end{array}$ & $\begin{array}{l}0.42 \\
0.5248\end{array}$ & 0.94 \\
\hline Hungary & 1958-72 & $\begin{array}{l}2478 \\
(656\end{array}$ & & & & $\begin{array}{l}1.52 \\
0.2297\end{array}$ & 0.99 \\
\hline Italy & $1958-95$ & $\begin{array}{l}687 \\
(0.2\end{array}$ & & & & $\begin{array}{l}0.24 \\
0.6259\end{array}$ & 0.98 \\
\hline Norway & $1958-95$ & $\begin{array}{l}-15897.21 \\
(273.80)\end{array}$ & & & & $\begin{array}{l}0.95 \\
0.3389\end{array}$ & 0.79 \\
\hline Sweden & $1958-95$ & $\begin{array}{l}-8305.59 \\
(234.80)\end{array}$ & & $\begin{array}{l}2.445 \\
(3.42)\end{array}$ & & $\begin{array}{l}2.07 \\
0.1629\end{array}$ & 0.98 \\
\hline Canada & $1922-56,1958-95$ & $\begin{array}{l}-4080.31 \\
(790.94)\end{array}$ & $\begin{array}{l}-0.053 \\
(0.36)\end{array}$ & $\begin{array}{l}1.530 \\
(4.88)\end{array}$ & $\begin{array}{l}1.596 \\
(4.94)\end{array}$ & $\begin{array}{l}8.54 \\
0.0063\end{array}$ & 0.99 \\
\hline U.K. & $1952-1995$ & $\begin{array}{l}-65.56 \\
(0.10)\end{array}$ & $\begin{array}{l}-0.037 \\
(0.17)\end{array}$ & $\begin{array}{l}0.347 \\
(2.72)\end{array}$ & $\begin{array}{l}0.375 \\
(2.68)\end{array}$ & $\begin{array}{l}2.37 \\
0.1335\end{array}$ & 0.99 \\
\hline Irelan & 94 & $\begin{array}{l}-4810.52 \\
(209.11)\end{array}$ & $\begin{array}{l}-0.259 \\
(2.18)\end{array}$ & $\begin{array}{l}-0.007 \\
(0.12)\end{array}$ & $\begin{array}{l}0.000 \\
0.00\end{array}$ & $\begin{array}{l}0.1 \\
0.7522\end{array}$ & 0.85 \\
\hline France & $1925-35,1946-94$ & $\begin{array}{l}-42233.80 \\
(416.91)\end{array}$ & & & & $\begin{array}{l}0 \\
0.9931\end{array}$ & 0.87 \\
\hline Finland & 1958-1995 & $\begin{array}{l}19853.24 \\
(939.42)\end{array}$ & $\begin{array}{l}0.141 \\
(1.15)\end{array}$ & $\begin{array}{l}1.322 \\
(5.28)\end{array}$ & $\begin{array}{l}1.361 \\
(5.19)\end{array}$ & $\begin{array}{l}1.04 \\
0.3172\end{array}$ & 0.99 \\
\hline U.S. & $1900-19,1935-50$ & $\begin{array}{l}90.476 \\
(2.33)\end{array}$ & $\begin{array}{l}0.076 \\
(0.30)\end{array}$ & $\begin{array}{l}0.553 \\
(2.68)\end{array}$ & $\begin{array}{l}0.566 \\
(2.50)\end{array}$ & $\begin{array}{l}0.14 \\
0.7142\end{array}$ & 0.97 \\
\hline U.S. & $1950-1995$ & $\begin{array}{l}74.91 \\
(0.71)\end{array}$ & $\begin{array}{l}0.542 \\
(3.15)\end{array}$ & $\begin{array}{l}0.330 \\
(0.70)\end{array}$ & $\begin{array}{l}0.321 \\
(0.67)\end{array}$ & $\begin{array}{l}0.28 \\
0.6016\end{array}$ & 0.98 \\
\hline U.S. & $1900-19,1934-95$ & $\begin{array}{l}7.25 \\
(0.38) \\
\end{array}$ & $\begin{array}{l}0.764 \\
(4.11)\end{array}$ & $\begin{array}{l}0.192 \\
(1.14)\end{array}$ & $\begin{array}{l}0.155 \\
(0.90)\end{array}$ & $\begin{array}{l}3.45 \\
0.0677 \\
\end{array}$ & 0.96 \\
\hline
\end{tabular}

Newey-West (1987) t-statistics in parentheses.

Coefficients on age and sex variables suppressed. For all but the U.S., the age variables used are the percentage of the population aged 15-19, 20-24, 25-29, 30-34, 35-39, 40-44, 45-49, 50-54, $55-59,60-64$, and 65 and over (the percentage under 15 is omitted). For the U.S., the age variables used are the percentage of the population aged 5-14, 15-24, 25-34, 35-44, 45-54, 55-64, and 65 and over (the percentage $0-4$ is omitted). 


\section{Table 6: States Passing State Level Prohibitions before Federal Prohibition}

Before 1900 Kansas, Maine, New Hampshire, North Dakota

$1907 \quad$ Georgia, Oklahoma

1908

1909

Alabama, Mississippi, North Carolina

Tennessee

$1912 \quad$ West Virginia

1914 Arizona, Colorado, Oregon, Virginia, Washington

1915 Alabama, Arkansas, Idaho, Iowa, South Carolina

1916 Michigan, Montana, Nebraska, South Dakota

1917 Indiana, New Hampshire, New Mexico, Utah

$1918 \quad$ Florida, Nevada, Ohio, Wyoming

$1919 \quad$ Kentucky, Texas

Note: New Hampshire repealed its 1855 prohibition in 1903. Alabama repealed its 1908 prohibition in 1911.

Source: Wickersham, v.5 (1931, pp.640-641). 
Table 7: Regressions of Cirrhosis on State Prohibition and Cirrhosis Rates by State, weighted by population

\begin{tabular}{lccc} 
& $1900-$ & $1900-$ & $1900-1997$ \\
& 1919 & 1950 & \\
\hline State Prohibition & 0.238 & 0.307 & -0.089 \\
& $(0.72)$ & $(3.38)$ & $(1.26)$ \\
Cirrhosis & & & \\
& 0.675 & 0.728 & 0.884 \\
& $(11.15)$ & $(24.52)$ & $(53.89)$ \\
Constant & 4.292 & 2.957 & 1.677 \\
& $(5.16)$ & $(7.85)$ & $(3.73)$ \\
Obs. & 347 & 1749 & 4145 \\
R-squared & 0.94 & 0.94 & 0.96 \\
\hline
\end{tabular}

Robust t-statistics in parentheses.

State fixed effects and year dummies included.

Observations weighted by state population.

$\%$ Decrease due to State Prohibitions

\begin{tabular}{llll}
\hline $1910-1920$ & $-0.84 \%$ & $-1.17 \%$ & $0.56 \%$ \\
$1920-1933$ & & $-10.24 \%$ & $0.19 \%$ \\
$1933-1950$ & & $-0.77 \%$ & $5.71 \%$ \\
$1950-1997$ & & & $1.96 \%$ \\
\hline
\end{tabular}

A negative entry indicates that state prohibitions increased cirrhosis. 


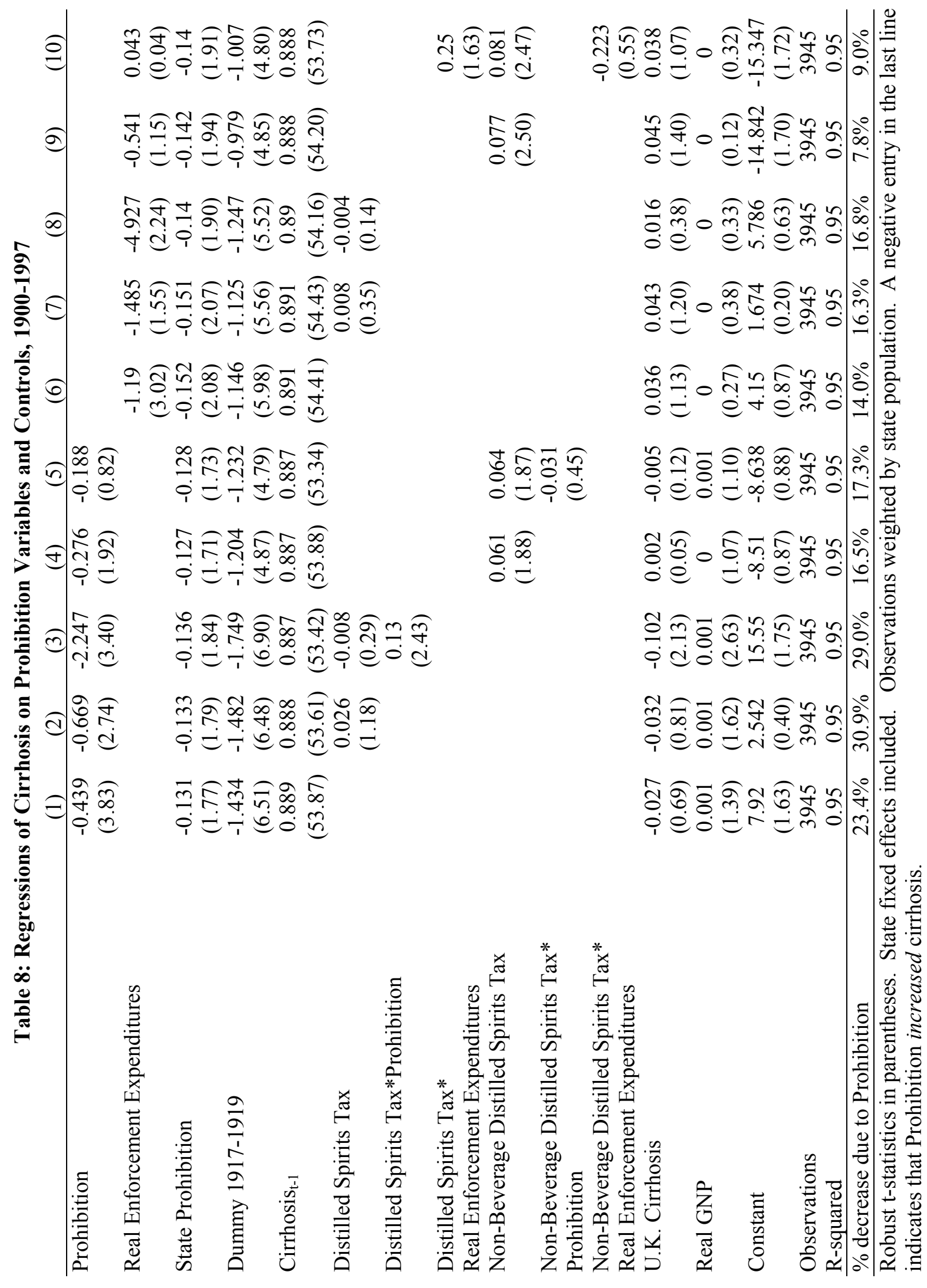


Figure 1: Average Cirrhosis and Average Alcohol

Consumption per capita, by Country

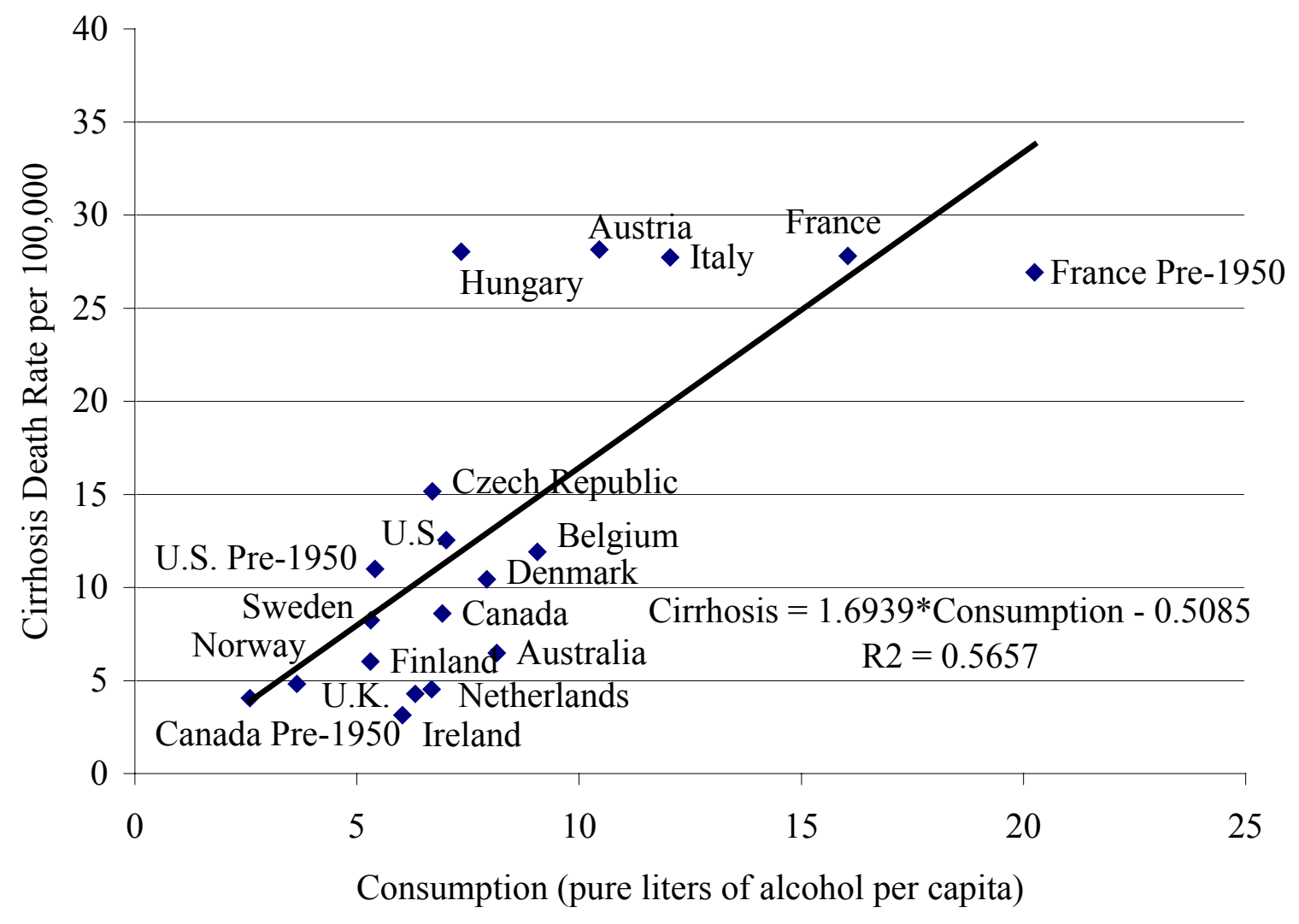


Figure 2a: International Cirrhosis Death Rates and Alcohol Consumption per capita

Cirrhosis

Australia

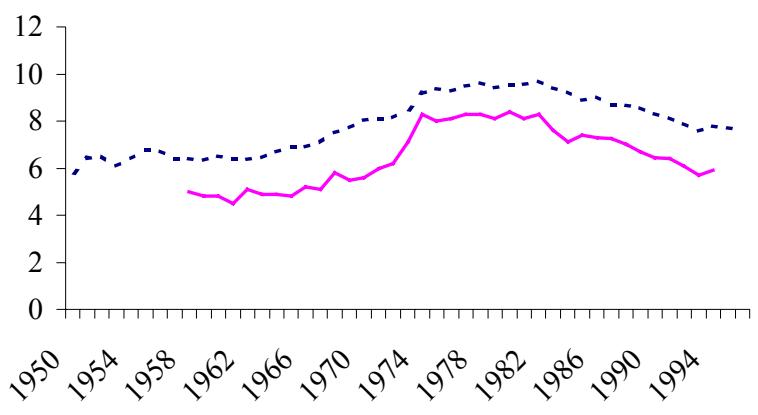

Belgium

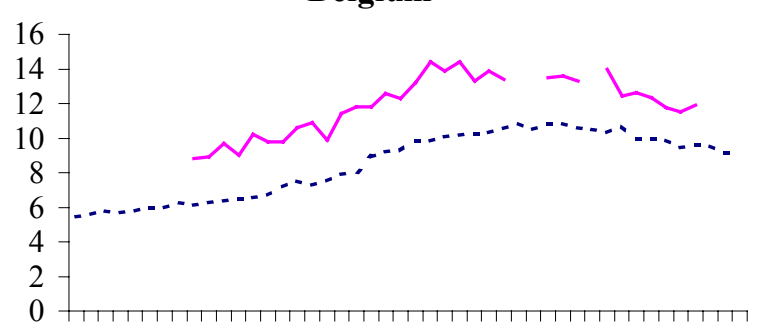

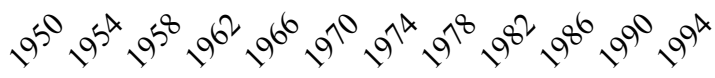

Czech Republic

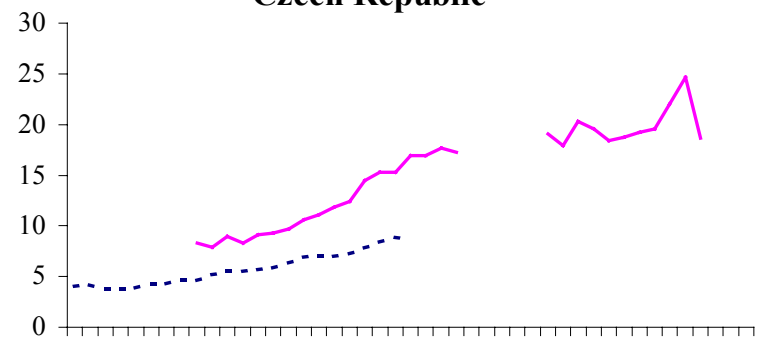

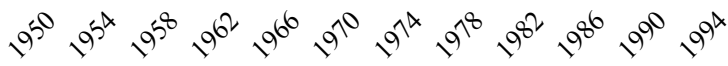

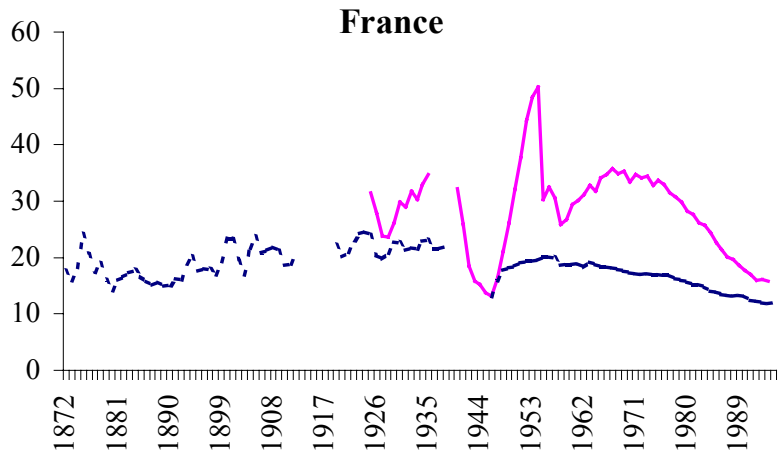

Consumption

Austria

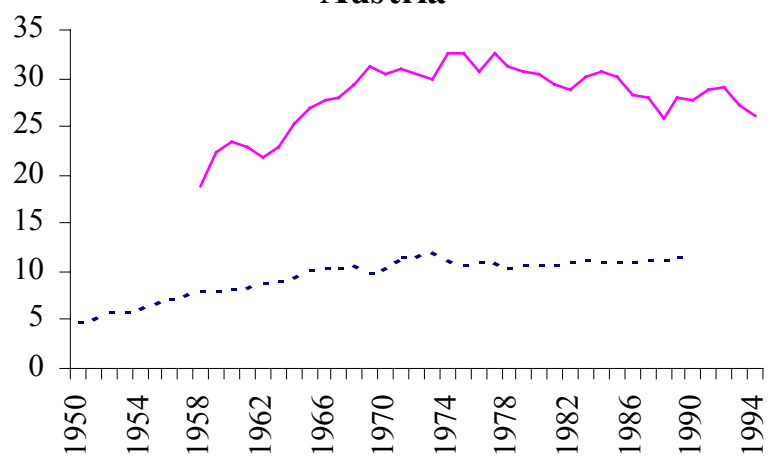

Canada

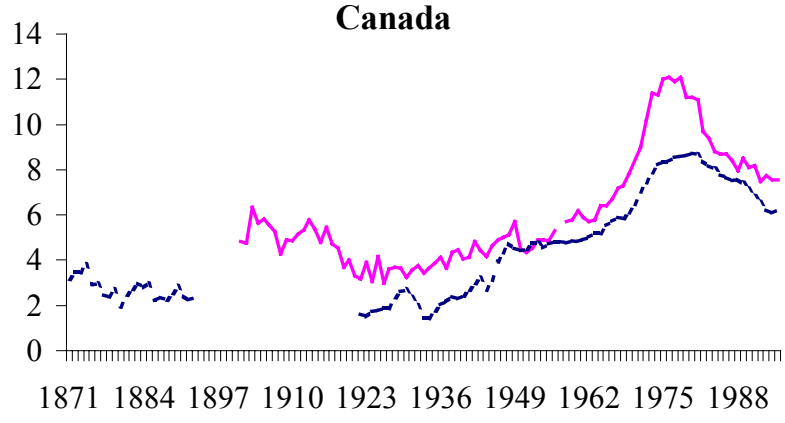

Denmark

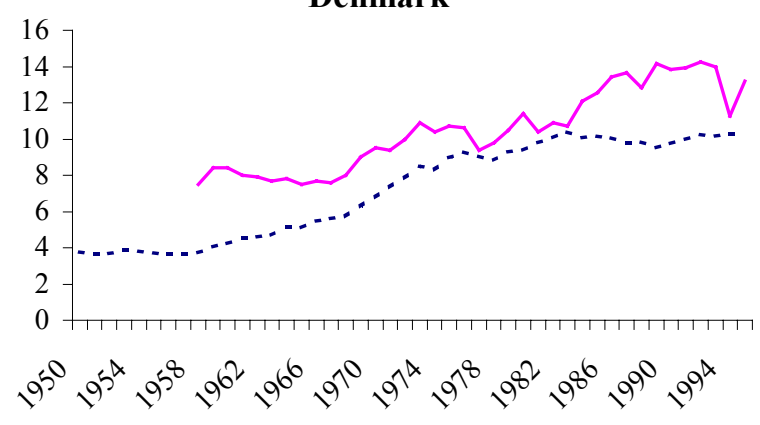

Finland

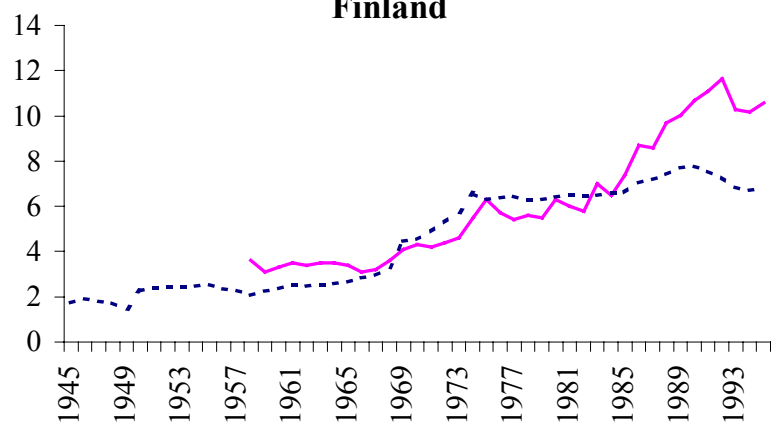

37 


\section{Figure 2b: International Cirrhosis Death Rates and Alcohol Consumption per capita}

Cirrhosis

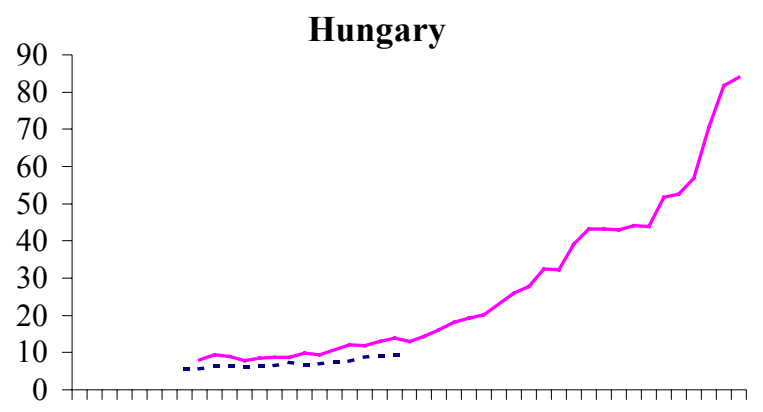

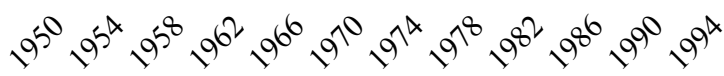

Italy

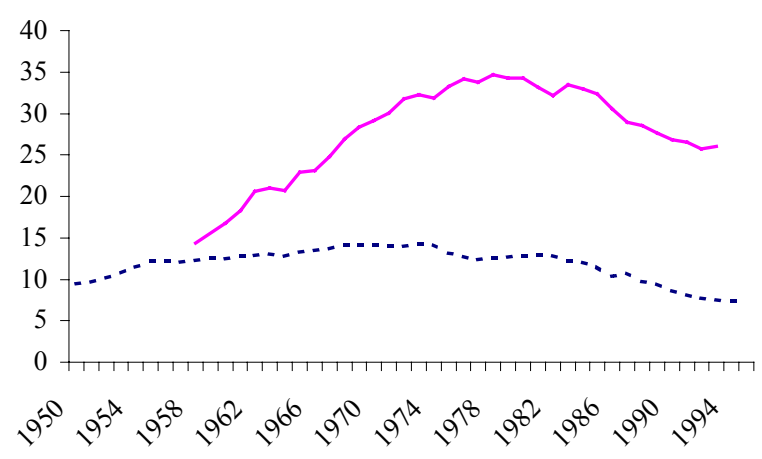

Norway

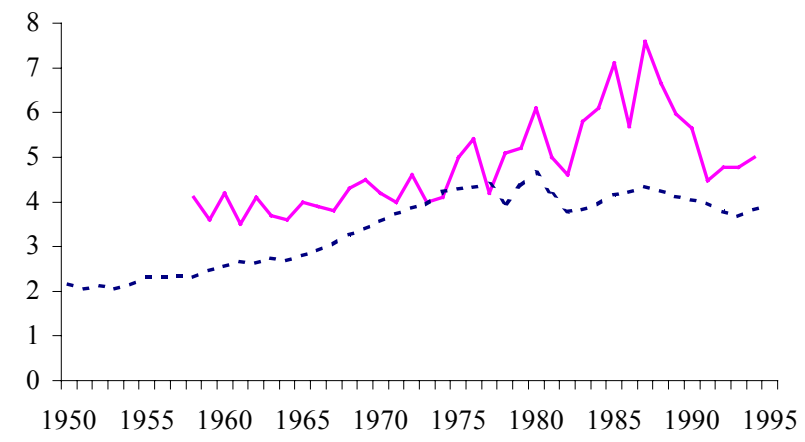

U.K.

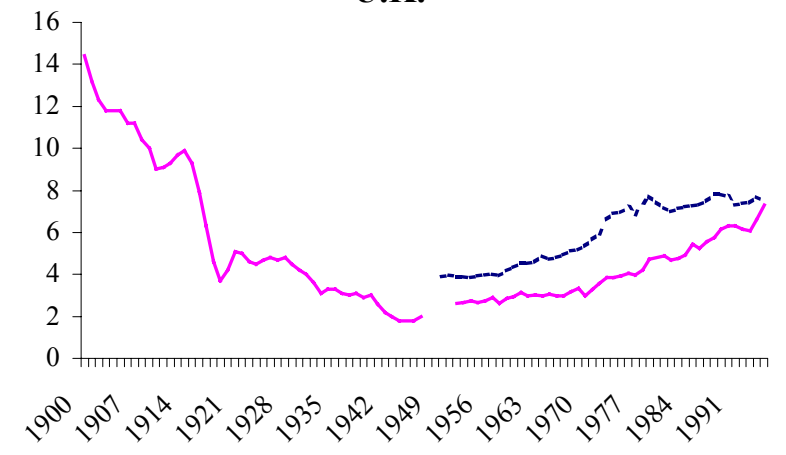

Consumption
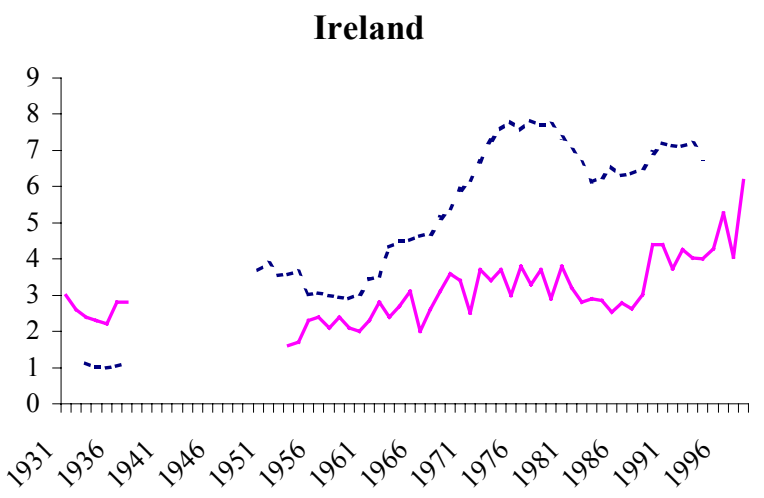

Netherlands

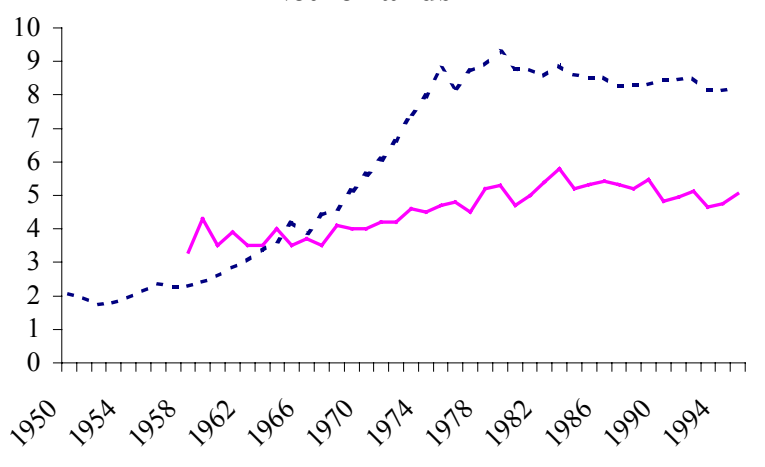

Sweden

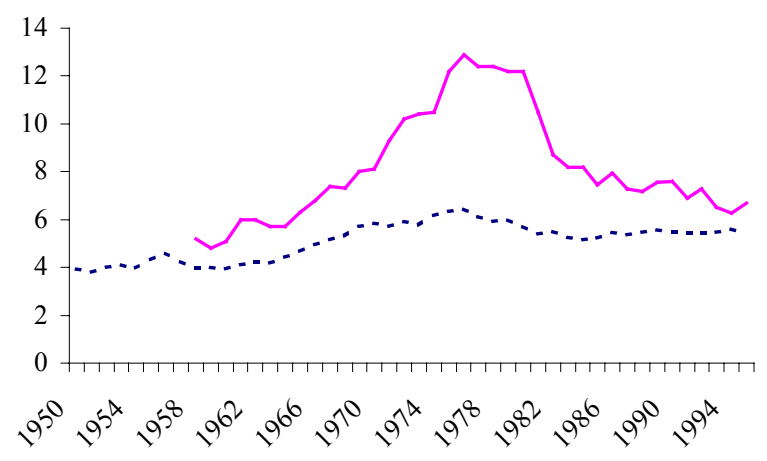

U.S.

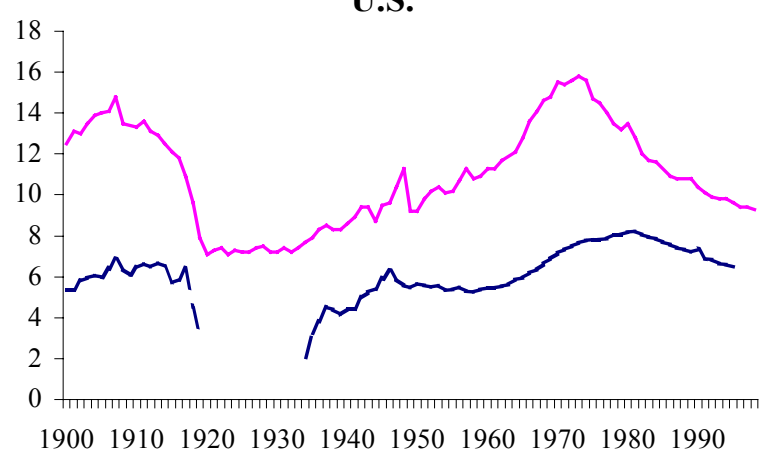


Figure 3: US Cirrhosis Death Rates per 100,000, 1900-1997

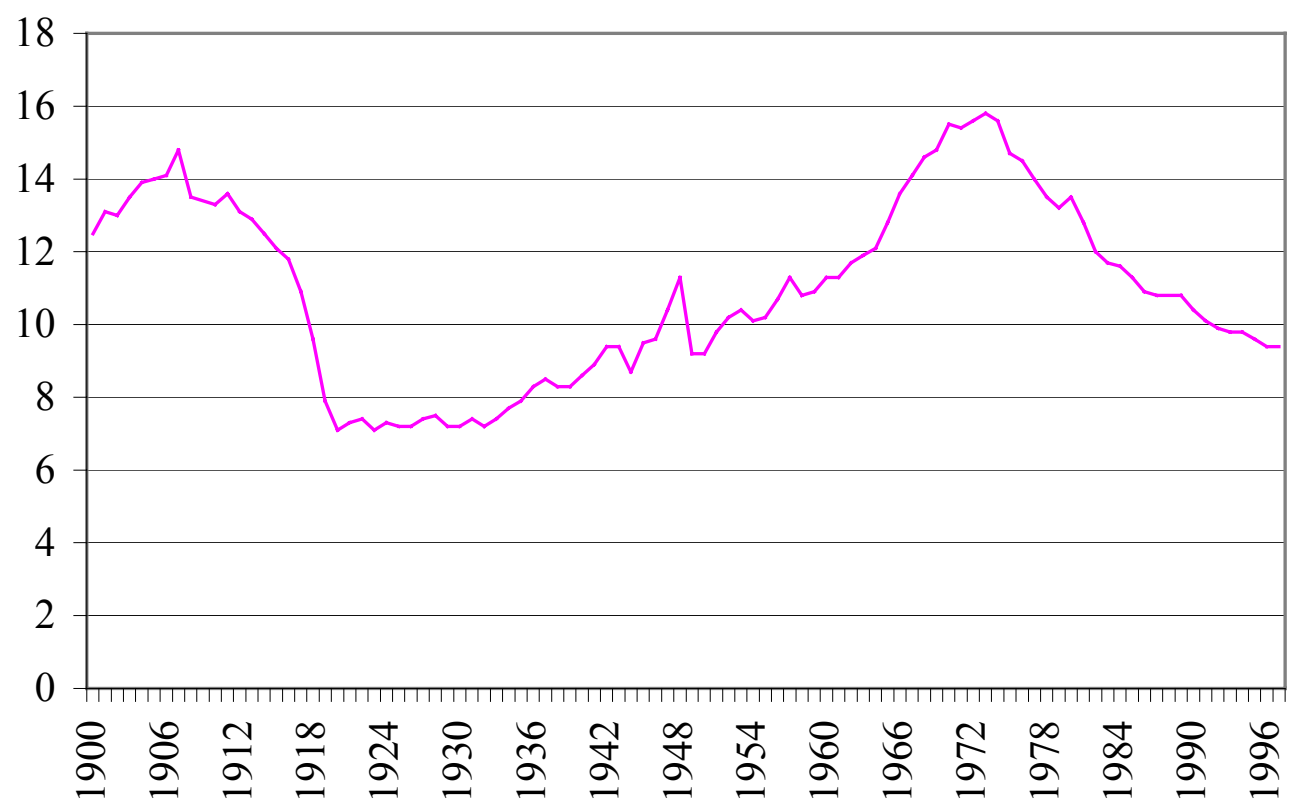

Figure 4: U.S. Cirrhosis Death Rates per 100,000 population, 1910-1940

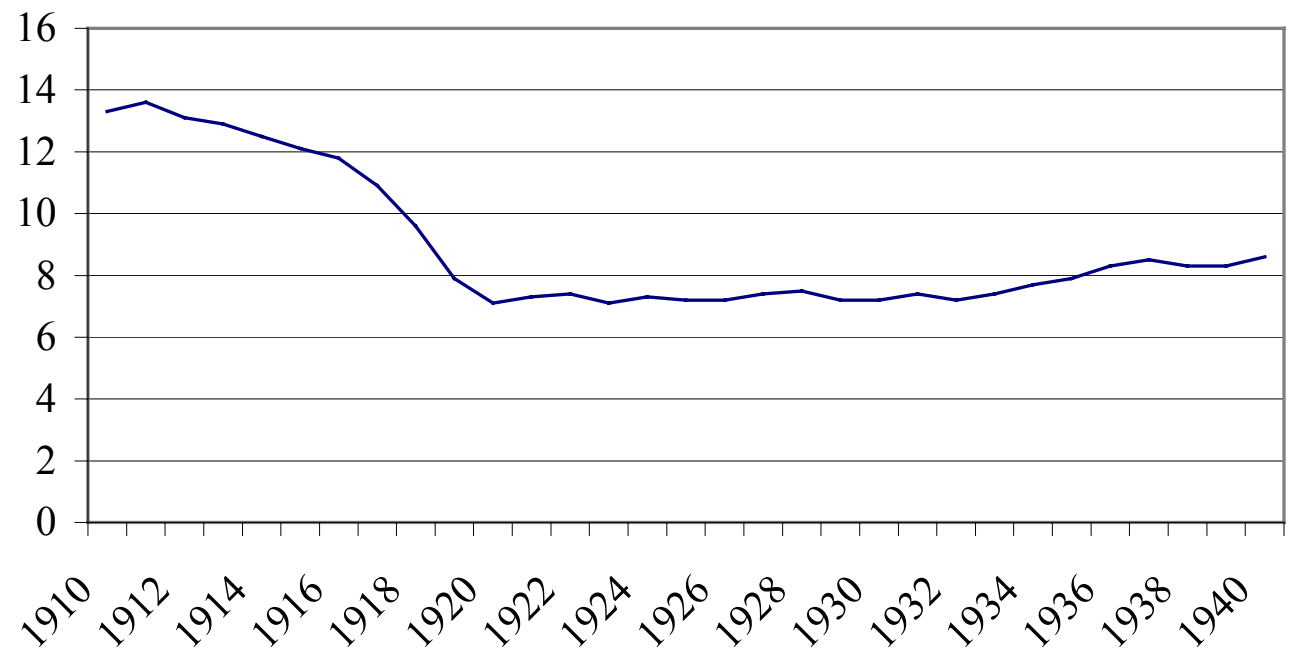


Figure 5: Cirrhosis Death Rates in States without Prohibition before 1919

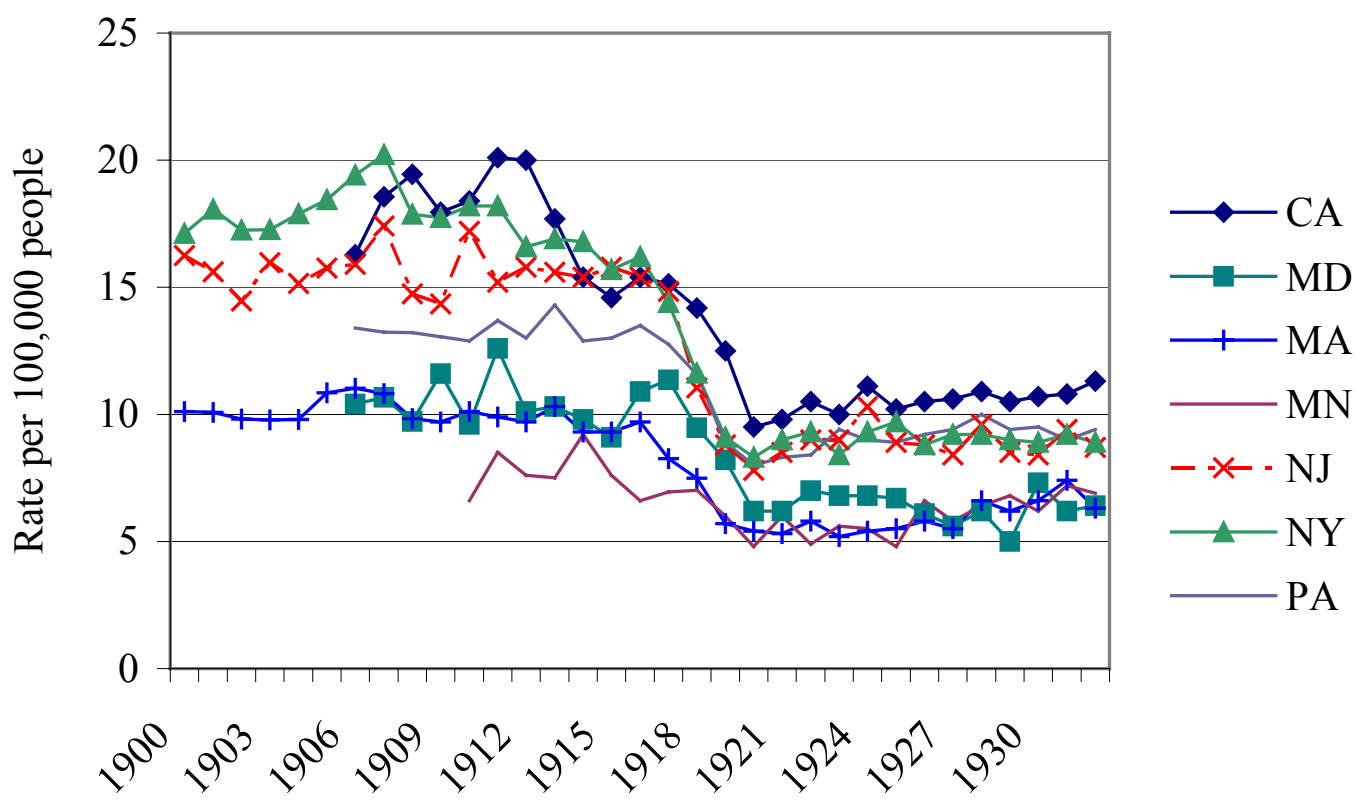

Figure 6: Cirrhosis Death Rates in States adopting Prohibition before 1919

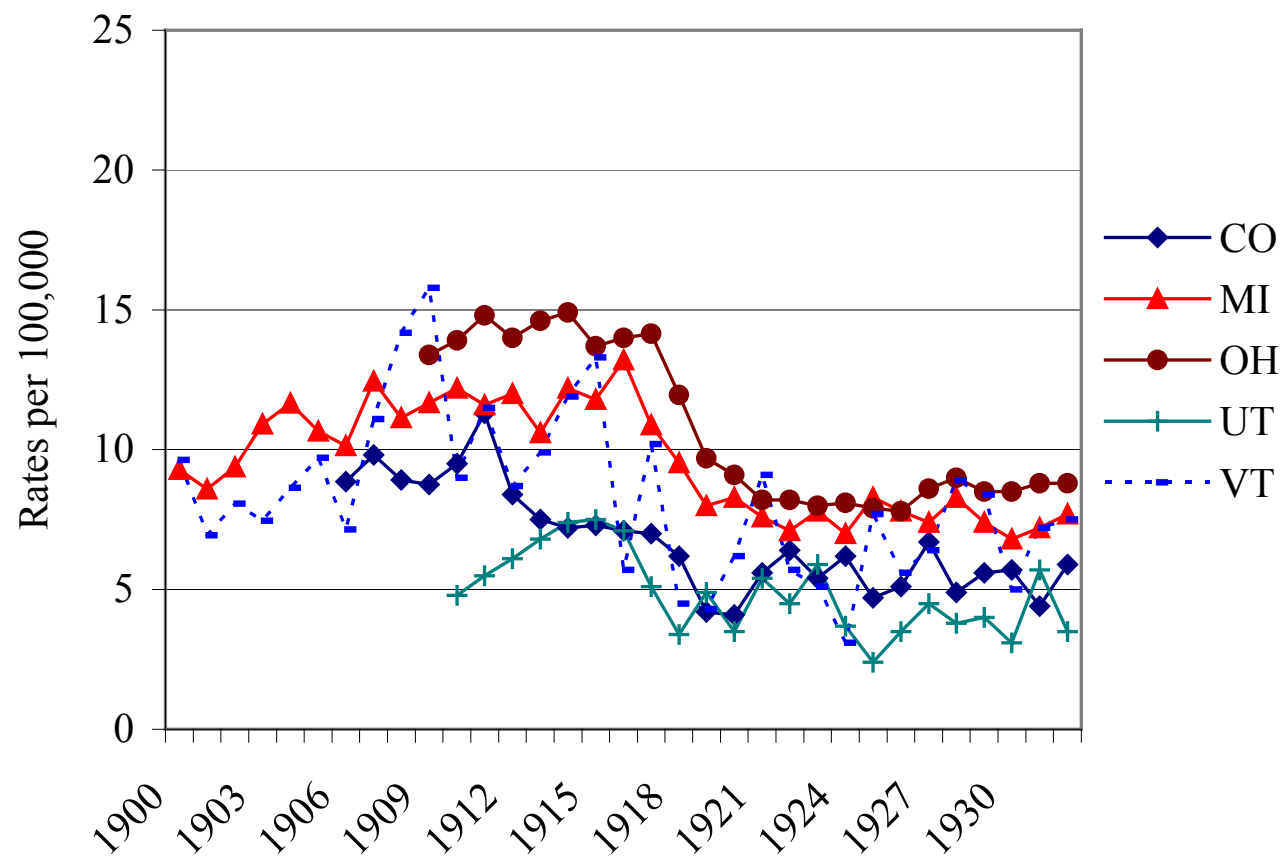


Figure 7: U.S. Cirrhosis Death Rate and per capita Alcohol Consumption, 1900-1920

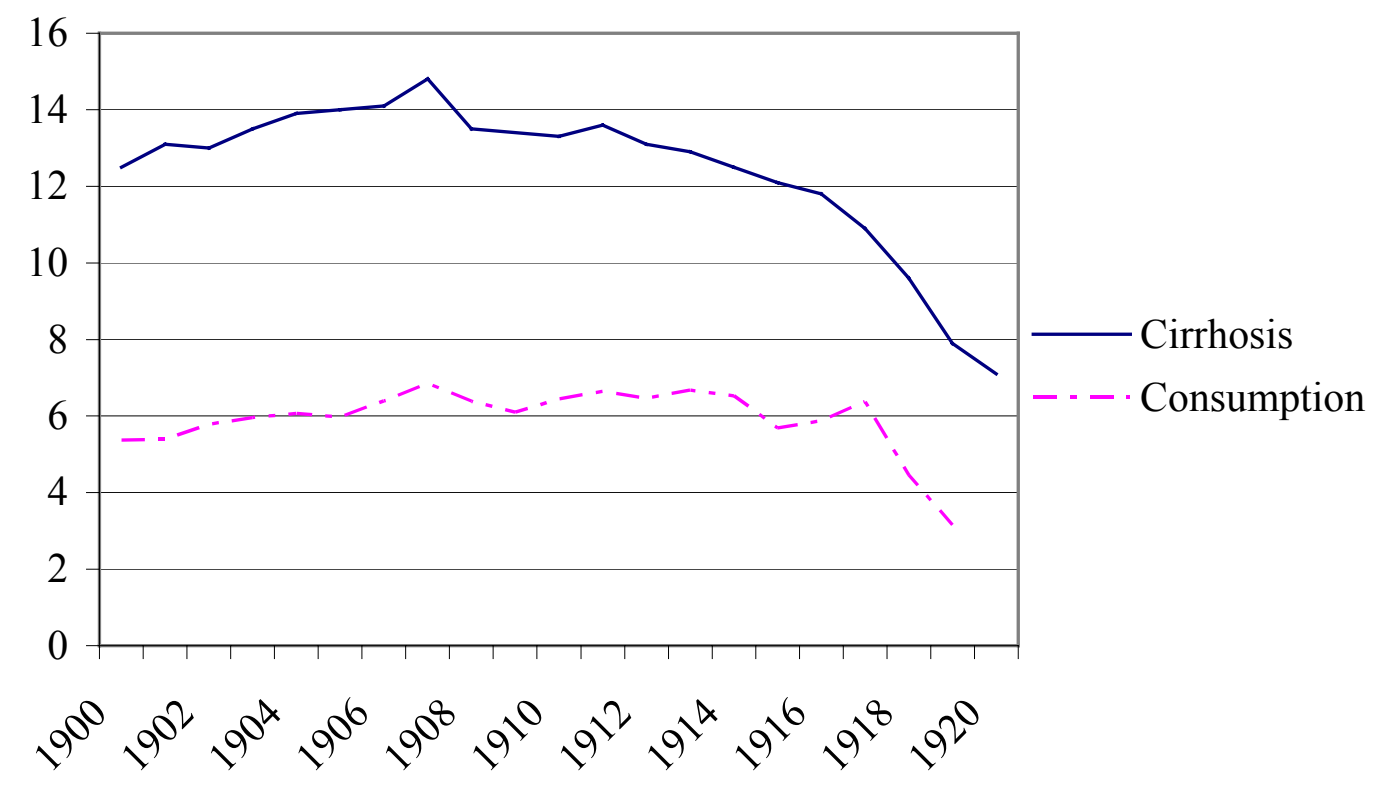


Figure 8a: Year Dummies Based on 1900-1997 Estimates of Equation (1)

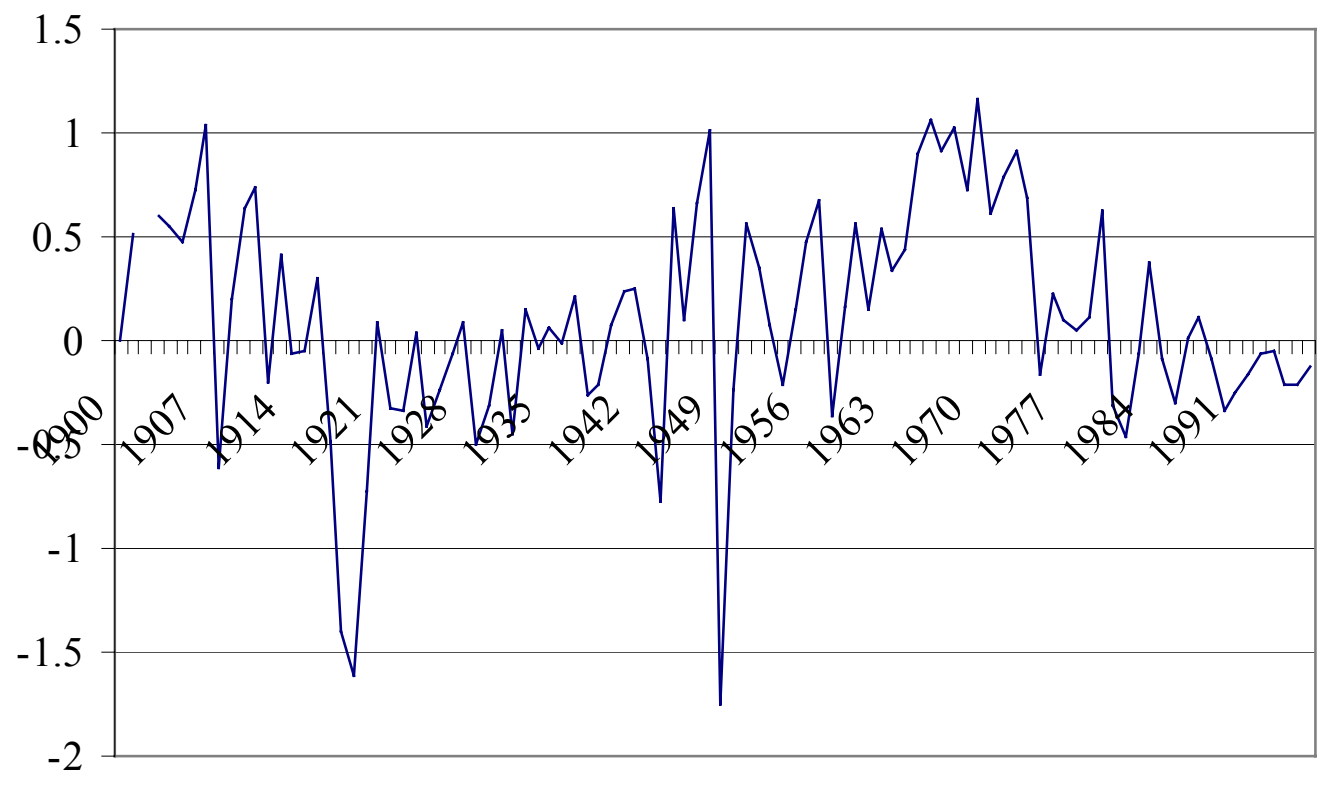

Figure 8b: Year Dummies Based on 1900-1950 Estimates of Equation (1)

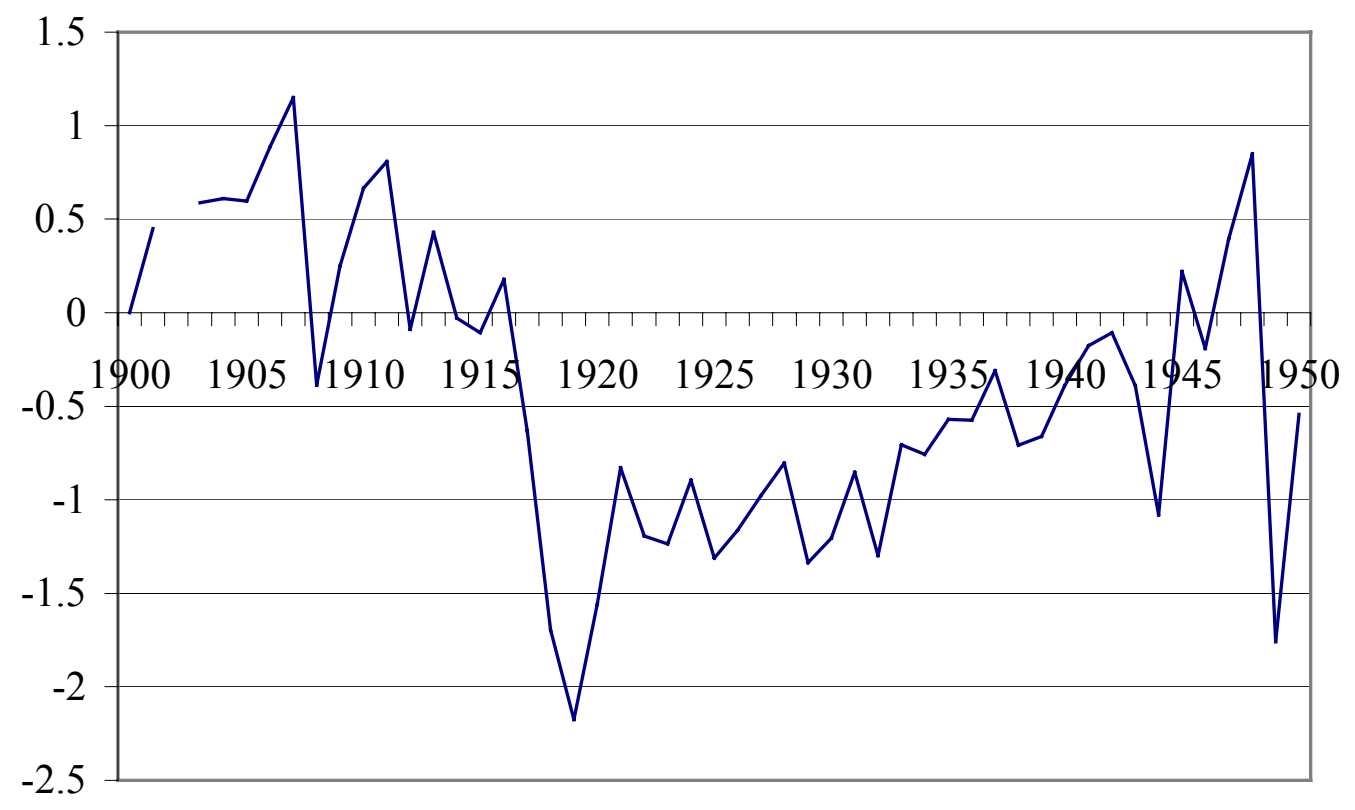

